\title{
Further Studies on the Apogamy and Hybridization of the Hieracia
}

(Experimental and Cytological Studies on the Hieracia, by C. H. Osrenfeld and O. Rosenberg, Part III)

by C. H. Ostenfeld, Köbenhavn (with Plate 4).

Contents.

Introduction . . . . . . . . . . . . . . . . 24I

I. Apogamy (Castration Experiments) . . . . . . . . . . . ${ }^{242}$

I. Subg^nus Stenotheca. . . . . . . . . . . . . . . . . ${ }^{243}$

2. Subgenus Archieracium . . . . . . . . . . . . . . . . . . 244

3. Subgenus Pilosella . . . . . . . . . . . . . . . . . 253

II. Hybridization Experiments . . . . . . . . . . . . 256

1. H. pilosella $\times$ atrantiacun . . . . . . . . . . . . . . 257

3. H. auricula $\times$ aurantiacum . . . . . . . . . . . . 257

3. H. excellcns $\times$ antantiacum ................261

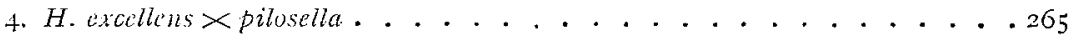

General results of the crossing . . . . . . . . . . 266

III. Apogany and its Relation to Polymorphism . . . . . . . . 267

IV. The Importance of Hybridization for the Origin of New Species, with special

regard to Hicracitm . . . . . . . . . . . . . . . . . . . . . 276

Literature . . . . . . . . . . . . . . . 282

\section{Introduction.}

In Igo6 I published a paper on some experimental investigations on the apogamy and hybridization of the Hieracia (OSTENFELD I906, 1907). It was the beginning of rather extensive studies on the reproduction of this interesting genus, which studies I am still pursuing and of which I shall here publish some results. I do not mean to say, however, that the investigations are near their end, far from it, and I can very well, repeat what I wrote in rgo6 (1. c., p. 247), "that at present we are only at the very beginning of our knowledge of these phenomena". In the meantime, however, I have discovered 
facts which, in my opinion, are rather interesting and which I think worthy of publication. They touch upon both problems, apogamy and hybridization.

As to the apogamy, a species has been found whose "races" differ in this respect, and we have here, in all probability, the apogamy in statu nascendi. And with regard to the hybridization it has become apparent that the first hybrid generation $\left(F_{1}\right)$ affords such a complexity of combinations of the characters ${ }^{1}$ ), while the later hybrid generations $\left(\mathrm{F}_{2}, \mathrm{~F}_{3}\right.$, etc.) breed true, that - for the one subgenus an understanding of the famous polymorphy of the genus is suggested.

A good deal of the following remarks may perhaps seem fragmentary; this is due, at least in part, to the fact that several experiments have failed, and that transplanting and the like have checked the investigation. Moreover, I have been away from the Gardens part of the summer every year, and the summer of rgog was so unusually rainy and cold as to greatly influence the thriving of the delicate species.

My friend, Dr. O. Rosenberg of Stockholm has, as before, taken his share in the experiments in that he has had collected materials for cytological use of all my experimental plants. I only need to point to his well-known cytological investigations on the Hieracia (ROSExBERG I906, I907), in order to show the benefit I have had from his. excellent collaboration.

I.

\section{Apogamy.}

\section{(Castration Experiments.)}

In Igo6 I summed up the results of my experiments on the apogamy of the Hieracia in the following way (1. c., p. 235): - „In

1) H. WinkLER (r9o9, p. 342) has advanced the theory: „Es scheint demnach, als sei es ein wesentlicher Unterschied des Pfropfbastardierungsprozesses von dem sexuellen Bastardierungsproze $B$ und für ihn besonders charakteristisch, da $B$ er nicht wie dieser eine im wesentichen homogene, sondern eine vielgestaltige Gencration $F_{1}$ liefert", and Strasburger (I909 b, p. 519) seems to agree with him herein and expresses himself still more explicitly, saying: ,.Pfropfbastarde, denen zudem die besondere Eigenschaft zukommen sull, daß sie nicht homogen wie sexuelle Bastarde, sondern vielgestaltig sind", and further: „Derartiges [verschiedene Kombinationen der Merkmale] ist für sexuelle Bastarde nicht bekannt." Both authors must have forgotten that heterogeneity in $F_{1}$ has been found in several cases in sexual hybrids. e. g. in Rubus and, already discovered by MenDel, in Hieracium. It is therefore not. a special property of the supposed grafting hybrids. 
the genus Hieracium we have apogamic and non-apogamic species together with transitions between both kinds. The three subgenera are in this respect not quite alike; the subgenus Sienotheca representing the most primitive stage with typical fertilization: the subgenus Pilosella being intermediate as it comprehends both apogamic and typically fertilizing species, nevertheless mostly apogamic; and the subgenus Archieracizm representing the most developed stage with nearly all species apogamic, only excepting the H. umbellatum group." This main result is still valid, but several details have been found, enlarging our knowledge of the phenomena.

\section{Subgenus Stenotheca.}

For the subgenus Stenotheca I have nothing really new to add; my plantings of the species of this subgenus have not been successful. These North American species seem to require a longer and warmer summer than we have in Denmark.

In the spring of 1908 I succeeded in getting seeds of H. Gronowii L., H. longipilum Torr. and $H$. scabrum Michx.; they were sown immediately at the end of April, but did not reach flowering that year. After wintering in pots in a frost-less place they were planted out in Ig09, but is was not till towards the end of September that a few specimens of $H$. Gronovii came to flowering, and then it was too late to try castration. No fruit, further, was developed in any of the plants left to themselves.

My plants of the only European species of this group, $H$. staticifolium Vill., did not fruit in I909, neither without nor after castration, so that I have nothing positive to say about this species either.

The plants of $H$. venosum $\mathrm{L}$, and $H$. Gronovii $\mathrm{L}$. used for $\mathrm{my}$ experiments in I905 (OSTENFELD I906) and their offspring died already in the winter I906-I907; they did not seem to be able to endure our winter, and in the summer of Igo6 they did not flower early enough to give ripe fruits. Thus I cannot say anything more about the reproduction in the subgenus Stenotheca than in my paper of rgo6, viz., that both the two hitherto examined species require normal fertilization in order to produce seeds capable of germinating.

It will be of great importance to have some more species of this subgenus examined, and I think it a promising task to an American botanist to subject this matter to examination. He will also be able, 
more easily than I am, to procure rich material of seeds. It will be specially interesting, if he could get seeds of the peculiar Andine species.

\section{Subgenus Archieracium.}

The castration experiments with species of the subgenus Archieracium have been continued in Ig06-Igog, always with new species, in order to examine as many as possible of the immense number of species of this subgenus. In this way it was hoped to ascertain how common apogamy is in this subgenus and whether certain sections perhaps differed from the others.

I think it appropriate here briefly to explain my method of investigation, whose main point is the so-called "castration" invented by C. RAUNKIAER (Ig03):

The seeds of the species to be examined are always sown in small pots with baked soil to prevent contamination by other Hieracia; when they have germinated, they are transplanted to somewhat larger pots with good nutritive soil (the baked soil is not good for the growth of the seedlings), and when they have reached a sufficient size, generally $5^{\mathbf{I}}$ ) individuals are planted out in beds. If the sowing has taken place in spring, some species come to flowering in autumn, and the experiments may then be made, but a good and plentiful flowering and favourable conditions for experiments are generally not obtained before the next summer. When the flowering has begun, a number of heads of one individual, and preferably in the same shoot of the plant, are chosen for castration; they must not yet have opened, but must be so near flowering, that it can be expected in 2 or 3 days. The castration is made by cutting off, with a sharp razor, the upper half of the head. By this operation are removed: the upper part of the involucral bracts, the corolla to the tube, the anthers and the upper part of the styles with the stigmas, besides the uppermost part of the pappus rays. There remain: the lower part of the bracts, the ovary and the lower part of the pappus. It is thus not a castration in the proper sense of the word, but an operation which removes both the male element and the conducting parts of the female element.

The castrated head becomes covered on the wounded surface with a quickly coagulating latex, which, however, later, as a rule, drops

1) In experiments to show the heterogeneity or homogeneity of crosses and the like, of course, all the material is used. 
off or is removed. Notwithstanding this violence, the heads of the apogamic species develop themselves undisturbedly and the fruits ripen as usual, but the heads are, in the ripe state, when they have opened, easily distinguished from the intact heads by the short pappus, which renders them much smaller in size and less conspicuous.

By this "castrating" process we would imagine that every possibility of fertilization has been removed. The objections which might be raised, can all be refuted, and they fall to the ground before the cytological investigations of ROSENBERG (I906, I907) in the apogamic species. The seeds of the castrated head are always sown in order to test their germinating power, and the plants raised are generally preserved till full development to compare them with their parents.

In the Hieracia - as in the other Compositae - not all the fruits in a head develop, so that they contain a seed capable of germinating. With a little practice one can rather èaily distinguish with great probability the full fruits (that is, those which have seeds capable of germination) from the empty ones, merely from their outer appearance. The empty fruits are generally somewhat smaller and more slender and of a paler colour (pale-brown to dark-brown), whereas the full ones are bigger and plumper and, in most species, of a black or black-brown colour (in some species brown in different shades, in a few species pale-brown, almost straw-coloured). The percentage of empty fruits in a head varies greatly in the different species, in the different plants of the same species, and even in the same plant, according to the season and from year to year, but the heads which ripen about the same time in the same plant have no doubt about the same proportion of empty fruits and full ones.

Now it may be supposed that this proportion is altered by the castration. This seems probable considering that certain species of the subgenus Pilosella, which produce fruits apogamically, are also able to hybridize, which requires a fertilization of those ovules that develop into seeds from which hybrids come forth. The investigations of ROSENBERG have also shown that in these species a few normally developed embryo-sacs are found. In such cases the number of full fruits should be smaller in castrated heads than in heads which have had an opportunity for pollination from the visits of insects, so numerous in these plants (especially of bees, humble-bees and butterflies).

By examining a sufficient number of castrated and non-castrated heads of the same plant one should now be able to decide the question. This means, in other words, to answer the question, whether the 
plant concerned has wholly lost the power of developing fertilized seeds or some flowers of each head require fertilization in order to produce seeds, while others develop seeds apogamically. I think that this way of solving the problem is better than that of the microscopical examination. Then, if only a small number of the flowers require fertilization, it is very difficult by means of microscopical investigation to find the rare stages in the development of the embryo-sac, which show the phases of chromosome-reduction and which consequently prove the necessity of fertilization ${ }^{1}$.

A difficult thing to find out is, how great a numerical material is required to get trustworthy results from these investigations, and here I am sorry to say that my material is hardly sufficiently extensive. My tables (I-III) show just that the greater the numbers are, the better the percentages agree.

In Igo6 I could enumerate I4 species of Archieraciznn in which I had found apogamy. As the tables (I and II) show, the number of forms has now increased to $\mathbf{6 0}$. The seeds of most of these I have had from various Botanical Gardens from their seed catalogues. The names under which these seeds were received have in many cases been wrong, and to get better determinations I applied to our best hieraciologist, Dr. H. DAHLSTEDT of Stockholm and asked him to determine my experiment-plants. I take here the opportunity of expressing my sincerest thanks to him for his obliging answer to my request. His determinations have led to the number of examined forms being considerably diminished; it comprehends only about 33 species, taken in a very wide sense.

The species examined belong to very different groups of the subgenus, and considering that among all the experiment plants only one species, viz. H. virga aurea Coss. - setting aside the forms of $H$. umbellatum $\mathrm{L}$. and the nearly allied $H$. lactaris Bert. - has not been found to be apogamic, I think $I$ am justified in saying that almost all the numerous species of the subgenus Archieracium are apogamic. There is no reason to go through the list of the single species, it must be sufficient to refer to the

1) I think it hardly correct, therefore, when S. Murbeck (I904, p. 294) concludes that, becaus: in three Hieracium species examined he never found pollen tubes in the style nor in the micropyle, "die drei betreffenden Arten sehr wahrscheinlich stets parthenogenetisch sind". The result is, in all probability, right, but the conclusion is not allowable. 
Table I, where they have been put down alphabetically. The species belong to both sections: Aurella and Accipitrina into which A. PETER (I894) in ENGLER \& PRANTL, Natürliche Pflanzenfamilien, divides Archieracizm, and almost all the 23 groups, into which the two sections have been divided, are represented. Of course, it would be desirable to get more of the aberrant species examined than $I$ have succeeded in getting into cultivation, but the seed catalogues do not present many more than I have got hold of, and otherwise it is difficult to get seeds. I may especially point out the desirability of studying the South European forms (mostly group Italica PETER) and the group Pseudostenotheca where differences might perhaps be found.

Of the species enumerated in the table, I may direct attention to H. alpinum L., var. Halleri Vill.; it has the peculiarity that the heads never open; the yellow tips of the corollas are seen peeping out of the bracts, but they do not reach farther. In spite of this, the plant has plenty of fruits with seeds capable of germinating. On the whole several forms of $H$. alpinum seem to have this peculiarity, in good harmony with the apogamy.

Further it is worth noticing that $H$, canadense Michx. which is classed among the group Unbellata, is apogamic, in contrast to its allies, H. umbellatum and H. lactaris. Furthermore, it is a native of North America, so that not all North American species require fertilization, as do the species of Stenotheca. - With regard to our northern Archieracia I think I can say that I have examined species of all groups and found that all are apogamic with exception of H. umbellatum.

If we turn to the question, if something can be said numerically whether the species are absolutely apogamic or not, I think that the numbers given in Table I permit the following conclusion: by far most of the examined species are absolutely apogamic. The percentage of full fruits is not disturbed by the castration in any degree worth mentioning, and the deviations go now to the one, now to the other side.

The numbers given under $H$. pulmonarioides Vill. present a fine example. Of this easily recognisable species I have had experiment plants from 4 different sources, and they formed fruits very well and did not show any dissimilarity in their outer appearance. Of these 4 sets one shows a slight tendency in favour of the castration (83:80 p. ct.); while the others go a little to the other side (97:99; $97: 98 ; 69: 76$ p. ct.); these numbers refer to a great many fruits and are therefore more trustworthy than many of the other numbers. 


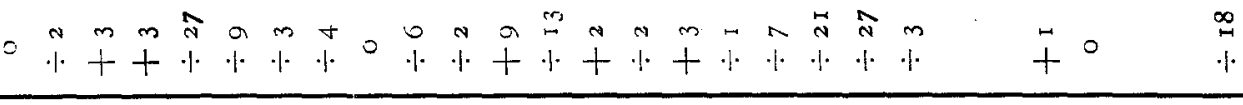

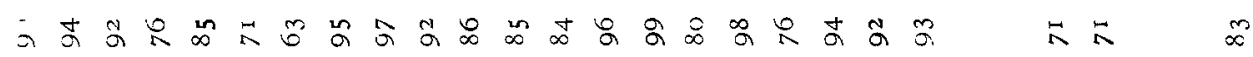

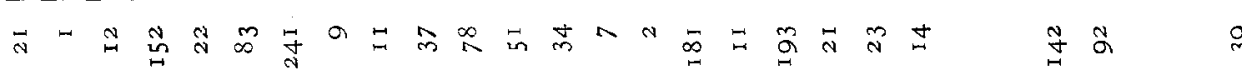

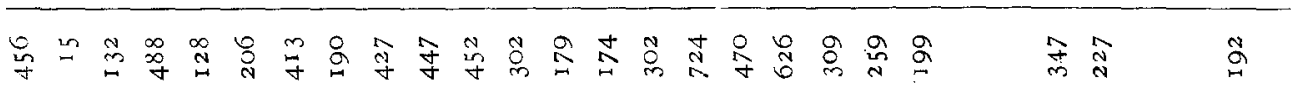

$0 \quad+20$ in in in

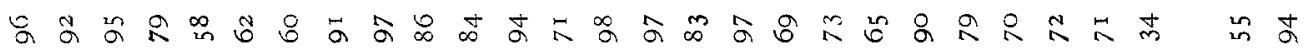

तิ

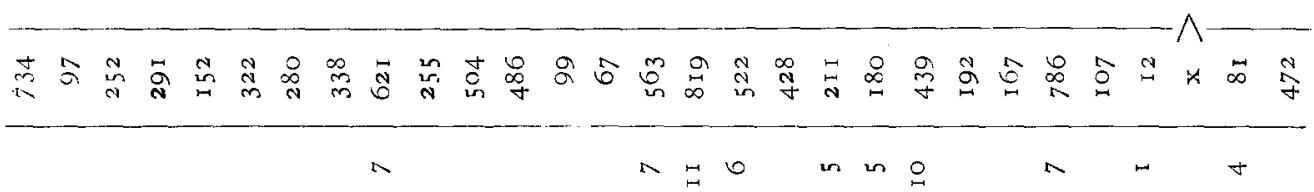

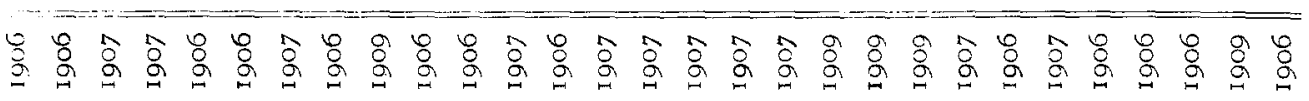

芯蓜

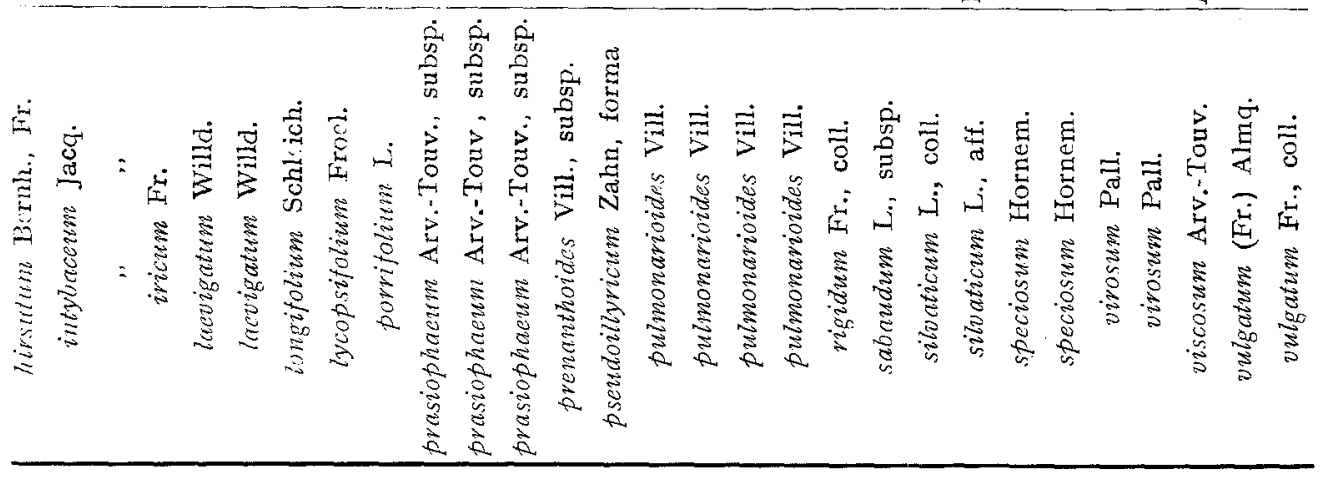

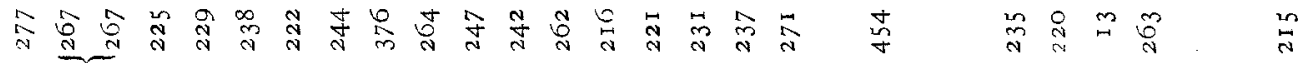


Of course these countings are based on gatherings of castrated and non-castrated heads of the same individual (generally even from the same shoot) and taken at the same time. How necessary it is to make the comparison only between gatherings from the same year is shown by the following case: in Igo8 the offspring of a form of H. boreale Fr. (from Lille) turned out in favour of apogamy (difference: 7 p. ct.), while in Igog the same individual gave the reverse result ( $8 \mathrm{p}$. ct. in favour of fertilization).

The objection that such a sorting from the outer appearance into full and empty fruits is uncertain and ought to be replaced by germination experiments, will apply in the same degree both to the castrated and to the non-castrated fruits and may therefore be dismissed as unimportant for a purely comparative consideration ${ }^{1}$ ).

If we go through Table I, we still find some deviations so considerable that we cannot explain them as casual. The above mentioned form of $H$. alpinum seems to have had advantage from the castration $(86: 66)$, but I think we ought not to regard this case as convincing, as only the fruits in one non-castrated head have been counted, and in these species with few and large heads the largeness of the heads varies considerably.

The other more noteworthy deviations are, $I^{0}: H$. sabaudum $\mathrm{L}$. where the castration no doubt has diminished the fruiting power $(65: 92) ; 2^{\prime}$, the case is similar with $H$. laevigatum Willd., of which there are countings of two different sets and of which one set has a great deviation $(58: 85)$, the other only a small one $(62: 7 \mathrm{I})$, both in favour of fertilization, $3^{\circ}$, and finally, a $H$. vulgatum Fr. and a $H$. rigidum Fr., both from Svendborg in Denmark, seem to show the same $(55: 83$ and $73: 94)$. As to these deviations, the differences in percentage between castrated and non-castrated fruits seem to indicate, that these species have not wholly lost the power of having fertilized fruits ${ }^{2}$ ). If we were to try to make hybrids within the Archieracia, we have here hints, which species we are to use.

1) In order to get an idea how great the germinating power is in the fruits considered as full, I have made a simple germination experiment, laying "full" fruits on wet filter-paper under glass in an ordinary room. The result was in one case 83 p. ct. germinated seeds, in another 70 p. ct.

2) The supposition is only of a restrained value, as the investigations are few, and most of the deviations are from 1909 with its rainy summer. Thus it is possible that the frequent rains may have had more influence on the heads made open through castration than upon the intact heads, which are protected by their bracts. 
Further Studies on the Apogamy and Hybridization of the Hieracia.

$25 \mathrm{x}$

\begin{tabular}{|c|c|c|c|}
\hline 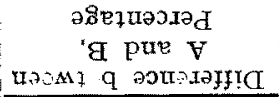 & & & $\begin{array}{l}\approx m=m=m \\
1+\cdots+\cdots+\cdots \\
\end{array}$ \\
\hline 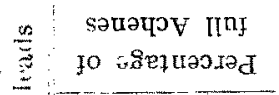 & $\infty$ & अ & 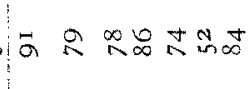 \\
\hline 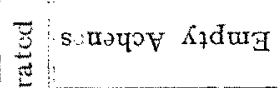 & 萬致 & 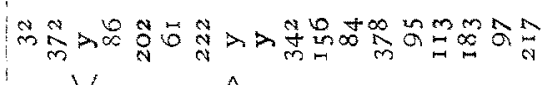 & 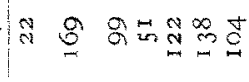 \\
\hline $\begin{array}{ll}3 \\
=\end{array}$ & $\stackrel{5}{2} \times \stackrel{2}{2}$ & 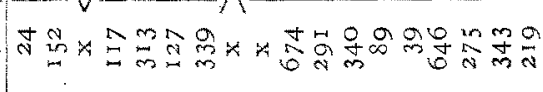 & 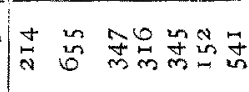 \\
\hline 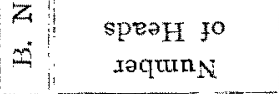 & & in in & $O \quad 0 \ln 0 \ln \infty$ \\
\hline 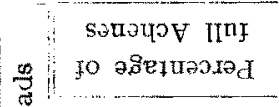 & 000 & 1000000000000000000 & 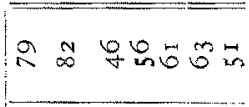 \\
\hline 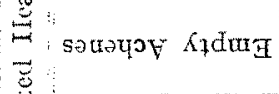 & 888 & 888888888888888888 & 욤 \\
\hline 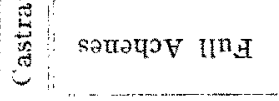 & 000 & 000000000000000000 & 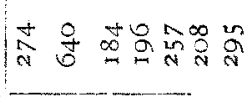 \\
\hline 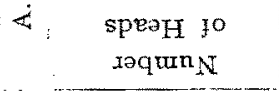 & & तो & $P \operatorname{lin} 0 \ln \infty$ \\
\hline 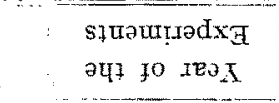 & $\begin{array}{l}8 \\
8 \\
8\end{array}$ & 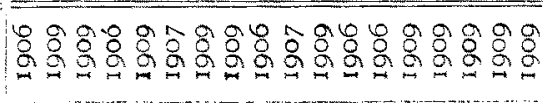 & 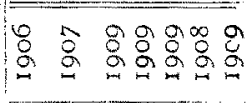 \\
\hline 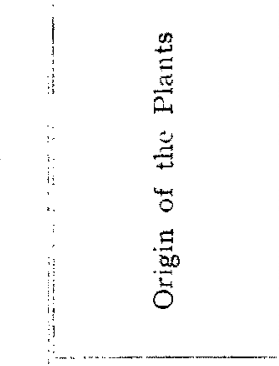 & 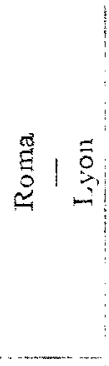 & 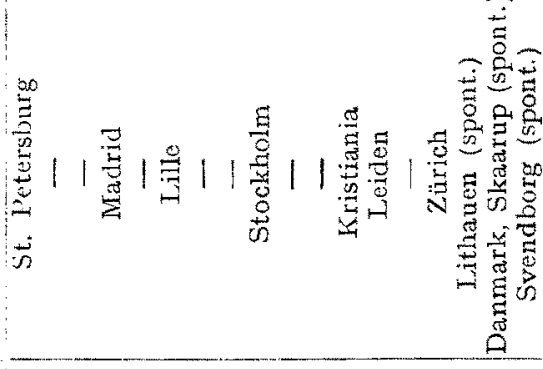 & 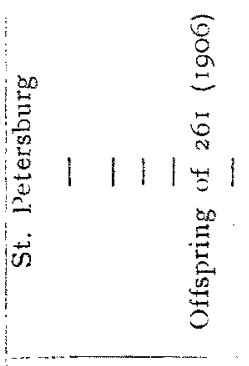 \\
\hline 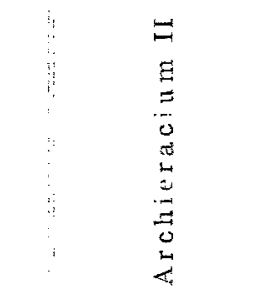 & 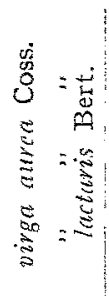 & 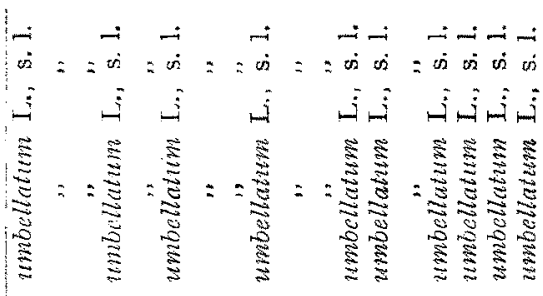 & 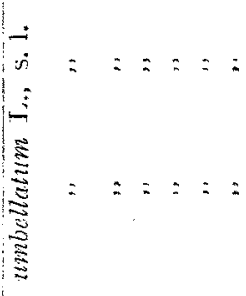 \\
\hline$\%$ & 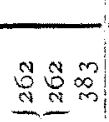 & 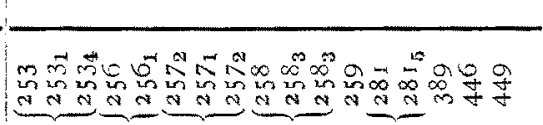 & 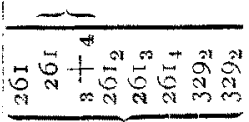 \\
\hline
\end{tabular}


The two sets of $H$. canadense Michx. give a tendency in farour of castration $(95: 86$ and $56: 45)$, while the form named H. canadenssc, aff. gives no tendency $(56: 56)$. Here more investigations must be made before an opinion can be expressed.

As mentioned above, $H$. virga aurea Coss. is not apogamic; I have tried castration several times, but always got the same result, that the heads are quite sterile if castrated. When left to itself, it fruits rather well, and from these fruits come a very heterogeneous offspring, which indicates that crossing must have gone on. It flowers too late, however, in our latitude to be a good experiment plant. -

Among the Archieracia is still left the group $H$. umbellatum, which I have studied more thoroughly, as it seems to me to be particularly interesting. When, in I905, it had become evident that four forms of this group required fertilization in order to fruit, or more correctly that they did not fruit after castration, I procured from the seed catalogues as many forms of this group as possible. I have in the years since then examined altogether twelve forms (sets), see Table II. From the castration experiments made in Igo6 I got the result that two sets of $H$. umbellatum were apogamic, the other sets not. I had, howerer, to go to work with caution, for the seeds received from the Botanical Gardens were so untrustworthily determined that not even the five experiment plants selected from a sowing were similar. For example, in 1906 in the one experiment, with a $H$. umbellatum from Lille, I got seeds after castration, while the two plants of the same set that were examined in I907 and Igog gave a negative result. The offspring of the apogamic individual - that evidently has been among the three of the five original experimental plants which died in the winter 1906-1907 - gave also fruit after castration, just as the parent had done. This dissimilarity is easily explained when we learn that the apogamic individual belongs, not to $H$. umbllatum, but to $H$. boreale, the seeds of which must have been intermingled with those of $H$. umbellatum; while on the other hand the two plants examined in 1907 and 1909 are true H. umbellatum. In consequence, the one case of apogamy in $H$. umbellatim has to drop.

The other set of $H$. amblellatum, which gave fruit after castration, is from St. Petersburg and was named $H$. umbellatum, var. Iinearifolium, but looks like a typical H. umbellatum. Dr. DAHLSTEDT confirms that it is a true $H$. umbellatum. There is then a form of H. umbellatum which is capable to fruit apogamically, but 
which in outer appearance does not differ from the other forms of $H$. umbellatum, which all require fertilization. The differences in percentage of full fruits in the apogamic form between castrated and non-castrated heads seem to indicate that the apogamy is not absolute $(79: 9 \mathrm{I}, 82: 79,45: 78,56: 86,6 \mathrm{I}: 74,63: 52$, and 5I:84). - All the other examined sets of $H$. umbellatum, including all those that proceed from spontaneous forms, and further the nearly allied species $H$. lactaris Bert., have not given any fruit capable of germination after castration and thus agree with the cytological investigations by O. JUEL (I905). We have thus in H. umbellatum the peculiarity that most of the forms, "races", are normally sexual, while a single form is apogamic ${ }^{1}$ ).

Looking through Table II it is curious to see how unlike the races of $H$. umbellatum are in regard to fruiting and how small the percentage of full fruits is in most cases. It seems to be a species whose fruiting at the present time is little stable and in which we might hope to find something to help us to an understanding of the mysterious phenomenon of apogamy. Still, I have as yet no hints of this understanding, but I hope that further investigations on this species will clear up the matter.

\section{Subgenus Pilosella.}

In my paper of Igo6 I could record that $H$. auricula $\mathrm{L}$. did not fruit after castration - which ROSENBERG's cytological investigations (r907) also confirmed - while the other five examined species of the subgenus Pilosella were able to do so. I have later repeated my experiments with $H$. auricula, also using other sets of this species, and with the same result. Connected with this fact is, no doubt,

1) In Rosa something similar seems to be the case. DINGIER (1907), who previously supposed apogamy in som: cases, cloubts that there is apogamy, and STRASBLRGER (1904) has shown that in the species examined, among others in $R o s a$ canina, the development of the embryo-sac is quite typical and that fertilization is necessary. On the other hand O. Rosenierg (1909, p. 155-158) has examined a form. R. canina, subsp. pirsaticifolia Almq., in which the development of the embryosac points to apogamy, consequently differing from the "race" of $R$. camina studied by Strastitirger.

Besides E. Lxxoström (1909, p. (16)) in a preliminary note has recorded, that he has had fruits developed after castration in $R$. virentiformis Matss. and in $R$. glauca vill., subsp. Afzeliana, var. dilatons Almq.. which latter according to RosENBERG (l. c., p. 156) must also be supposed apogamic.

It is remarkable that the number of chromosomes in the apogamic race of 1R. carina is abont double what it is in the normally sexual race of the same species. 
the pronounced disposition of this species to hybridize, as will be mentioned later.

All the other species of Pilosella examined in I906-I909 have been able to give fruit after castration. My investigations, unfortunately, do not comprehend so many species as is desirable - altogether 23 sets belonging to $\mathrm{I}_{4}$ species. The species of Pilosella have comparatively small heads and are therefore, technically, rather difficult to castrate, the heads easily being spoilt during the operation, especially in the very small-headed forms. The small fruits are also difficult to count from their outer appearance, and in several species each head gives few fruits. All these circumstances impede the investigation. The countings tabulated in the Table III are therefore much more incomplete than in the case of Archieracium, and the numbers given are admittedly too small. Still, I think they point to the general conclusion that the number of full fruits is somewhat diminished by castration - in other words, that the apogamic species of Pilosella are not absolutely apogamic, but that some of the flowers of each head require fertilization.

There are altogether 7 sets that can be used for comparison. and, of these, five distinctly point in the direction named. Of the two pointing the opposite way, one (H. florentinum All.) at least is too insufficiently investigated, as the numbers are small. The other is a set of $H$. aurantiacum and is hardly very convincing. Just about this species MENDEL (CORRENS I905) has written, that it is absolutely unable to be used for crossing experiments (that is to say as mother plant, but its pollen can very well fertilize other species), and this would agree well with its being absolutely apogamic. Further, another set of $I$. aurantiacum gives the opposite result. The general conclusion from these cases is, therefore, in my opinion, that the countings given are without value, so far as $H$. aurantiacun is concerned.

Although the experiments with species of Pilosella are not so comprehensive as they ought to be, we may sum them up in the following general sentences: Within the subgenus Pilosella the species $H$. auricula is absolutely sterile after castration"), while the other species examined are capable to fruit apogamically, yet apparently in such a way that, at least in most species, a small part of the flowers require fertili. zation. This result agrees with RosENBEIRG's cytological investigations (1907) and with the great number of hybrids known in this subgenus.

$\left.{ }^{1}\right)$ Several experiments seem to indicate that it is even self-sterile. 
Further Studies on the Apogamy and Hybridization of the Hieracia.

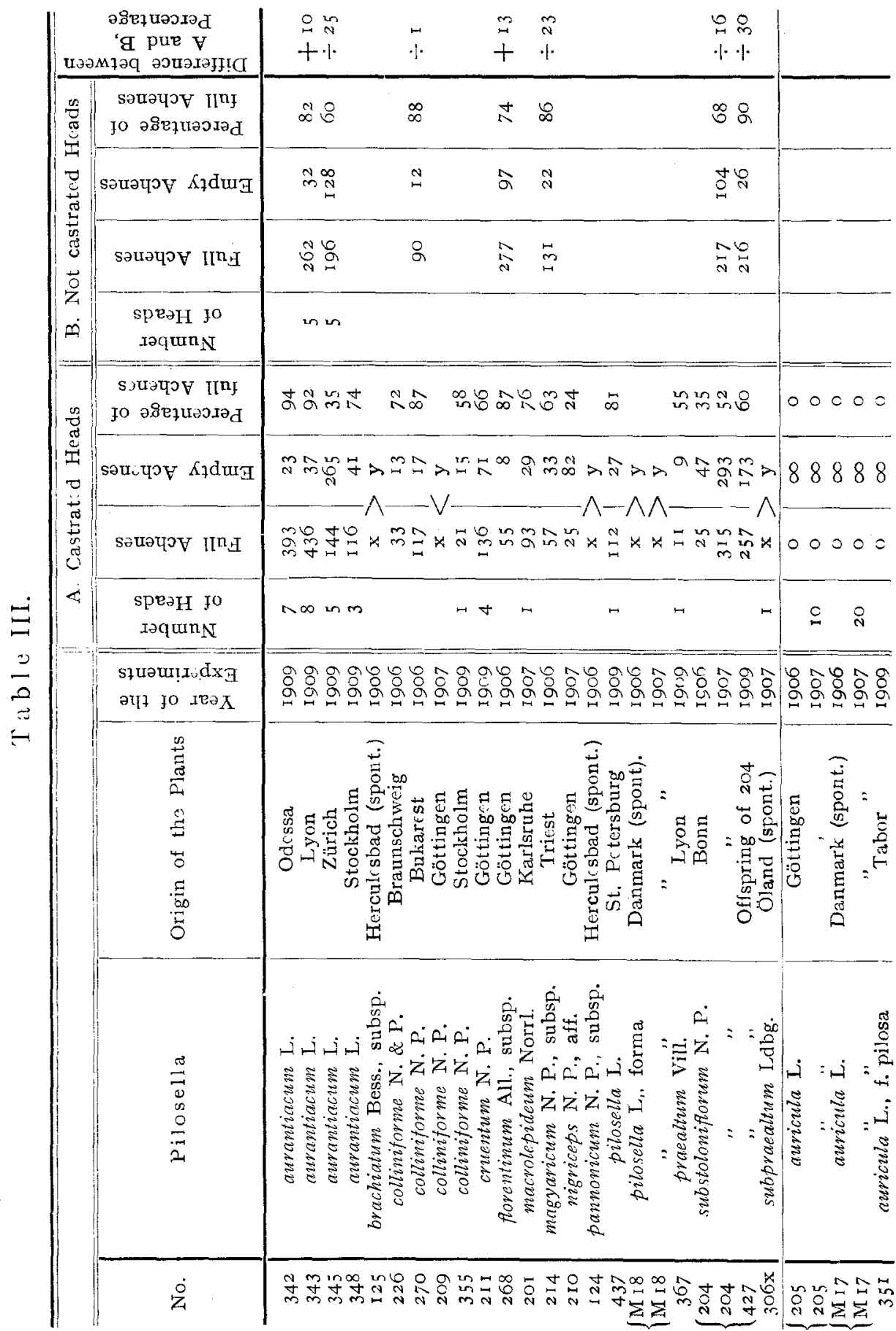




\section{II.}

\section{Hybridization Experiments.}

In my paper of 1906 I reported that I had artificially produced the following hybrids:

\section{H. pilosella $\times$ aurantiacum \\ H. excellens $\times$ aurantiacum. \\ H. excellens $\times$ pilosella.}

My method of crossing was as simple as possible: I isolated under bell-jars before unfolding some heads of the plants I wished to use. When a few days later the heads had opened - at any rate the outer flowers of the heads - I picked off the head whose pollen was to be used and rubbed it cautiously to and fro over the stigmas of the head of the plant to be used as mother parent; this manipulation was sometimes repeated one or two days later with a new head of the father plant, but with the same one of the mother plant in which now the more central flowers of the head had opened. The head thus pollinated was kept continually under the bell-jar, closed below with wadding, until sometime after the flowers had withered. As soon as the withered corollas, on touching, easily dropped off in a clump, the wadding was removed, as it caused the air in the jar to be continually saturated with vapour and thus sometimes furthered an attack of mould on the heads. The head was now permitted to ripen under the bell-jar, but with free access of the air from below. The jar only served to prevent the ripe fruits from being carried away by the wind, if the gathering happened to be a little delayed. In the sowing of the fruits, the same precautions were taken as have been mentioned under the castration experiments.

This method, which I still use, is thus much simpler than that used by MENDEL (I870) and F. Scrrultz ( 1856 ), and it has the shortcoming that it does not give results which can be used for counting, self-fertilization (when the mother plant is hermaphrodite) not being excluded; but I consider it as the only easily practicable method when working with Compositae that have small flowers.

F. SCHULTz transferred, by means of a fine brush, the pollen on to the stigmas, but did not take special precautions against selffertilization; his method is thus not more exact than mine, but more difficult to carry out.

On the other hand, MENDEL's method is the most exact; by means of fine pins he removed the anthers before the opening of the flower 
(most of the flowers of the head were taken away) and fertilized the thus rightly castrated flower with the pollen of the father species. This method, however, is so difficult and gives such small results, as the delicate flowers are often destroyed in the operation, that a patience and dexterity like MENDEL's are required in order to employ it.

In the following I shall give the results of my crossing-experiments, obtained since I905, especially the results of the study of the later generations of the first produced crosses, together with a report of a new cross.

\section{H. pilosella $\times$ aurantiacum.}

In 1904 I had obtained a hybrid (No. 55) by crossing $H$. pilosella with $H$. aurantiacum. The single individual of this cross (represented in the plate af the 1906 paper as fig. 7) did not fruit in 1905 after isolation or castration, in contrast to both parents. But when the heads were left to themselves during flowering, a few full fruits were developed, from which plants arose, different from one another and to be considered as the result of new crosses caused by visits of insects. Some of these were apparently pure $H$. pilosella and might be supposed to be segregations, by back-crossing with the mother parent.

The castration was repeated in 1906, I907 and 1909, but always with negative result. Isolation of some few heads was also tried, but no fruit capable of germination was obtained in that way either. The hybrid may thus be regarded as self-sterile.

An experiment of crossing it with the pollen of the father plant (H. aurantiacum) has until now given only a single individual as offspring; this was very much nearer to $H$. aurantiacum than was the primary hybrid, but was still not a pure $H$. aurantiacum and was also quite sterile ${ }^{1}$ ).

\section{H. auricula $\times$ aurantiacum.}

As before mentioned, $H$. auricula requires fertilization in order to produce fruits capable of germinating, and it was therefore to be

1) An experiment with similar result has already been made by MENDEL (CoRrens 1905, p. 245) by crossing the hybrid H. praealtum $\times$ aurantiacum $(=H$. magyaricum $\times$ aurantiacum) with $H$. aurantiacum. He got as offspring: ,zweierlei Pflanzen, solche nämlich, welche mit der Bastard-Mutterpflanze ganz übereinstimmten, und andere, welche dem $H$. auraniiacum um vieles näher standen." The former of these categories is evidently apogamic $F_{2}$, while the latter corresponds to my experiment. 
supposed that this species would be favourable to crossing experiments, as, indeed, MENDEL had already pointed out. He writes in a letter to NAGELI (CORRENS I905, p. 230) that: " $H$. auricula ist . . bei einiger Vorsicht eine vollkommen verläßliche Versuchspflanze". He has crossed more than a hundred heads of this with several other species, and whenever he got fruits capable of germinating, they always gave rise to hybrids ("allein die aus denselben erzogenen Pflanzen sind ohne Ausnahme Bastarde"; CORRENS I905, p. 230).

In his short paper on Hieracium MENDEL (1870, p. $5 \mathrm{r}$ ) already mentions that by crossing $H$. auricula with $H$. aurantiacum he got two specimens of the same cross differing from each other, one redflowered and quite sterile, and one yellow-flowered in which "ein einziger gut ausgebildeter Same", appeared. In his letters he repeatedly mentions this hybrid combination, a great number of which he has produced. For example, in a letter of 1870 he reports that he has planted 98 specimens out in his garden; of these, 84 flowered in the same year, some died, and others did not reach flowering. About the flowering specimens he says (CORRENS I905, p. 238): "Die Abweichungen unter denselben sind sehr beträchtlich. Jedes BastardMerkmal erscheint in einer gewissen Anzahl von Varianten, welche Übergänge von einem Stamm-Merkmale zu dem anderen darstellen. Es scheint, daB die Varianten der verschiedenen Merkmale miteinander in allen möglichen Verbindungen auftreten können. Das letztere wird dadurch wahrscheinlich, da $B$ an den vorhandenen Bastardpflanzen die Anordnung der Merkmal-Varianten eine außerordentlich mannigfaltige und kaum in zwei Fällen eine völlig gleiche ist." And further (l. c., p. 239) that: "etwa der vierte Theil als vollkommen fruchtbar, die Hälfte als theilweise und ein Viertel als ganz unfruchtbar zu bezeichnen ist. Der Grad der Fruchtbarkeit erscheint als unabhängig von der Form des Bastardes". Once more this hybrid is mentioned in MENDEL's letters (1. c., p. 243), when he says that in I87r he put down the following remark on it: "Circa 9o Bastarde zum Theile fruchtbar, sehr verschieden". The last words have been written to show the contrast to crosses between $H$. auricula and several races of $H$. pilosella, in which crosses all the specimens of each cross were alike.

My experiments are, strictly speaking, only repetitions of those made by MENDEL; but the fact that $H$. aurantiacum is capable to fruit after castration and consequently is, at least in part, apogamic, throws a new light on the matter. 
a. The $7^{\text {th }}$ of July rgo6 I pollinated an isolated head of $H$. auricula (the same set which was used for castration experiment; No. M I7) with pollen from an isolated head of $H$. aurantiacum (this too had been used - and with positive result - for castration experiment; No. 58). Only four specimens appeared from the sowing of the seeds gathered, and these were all hybrids, all unlike each other, standing in their characteristics in different degrees between the parents. No correlation seems to exist between the different characters; e. g. a hybrid, in colour of the flowers near to $H$. aurantiacum, does not also in other characters resemble the father.

With regard to the colour character the family showed the following gradation:

I specimen (No. $286_{1}$ ) was very near to $H$. aurantiacum.

I specimen (No. $286_{3}$ ) was less near than the preceding, but still nearer to the father than to the mother.

I specimen (No. $286_{2}$ ) was intermediate or perhaps a little nearer to the mother.

I specimen (No. $286_{4}$ ) died before I had noticed its flower colour; it was a decided hybrid.

The first two specimens do not seem to be able to have full fruit; at least, it appears from castration and isolation experiments, that they are self-sterile. The third one (No. 286 2 ), however, has yielded fruit after castration. Already under the first scanty flowering in autumn 1907 one head was castrated. The small number of fruits gathered from this experiment were sown in May I908, and the plants $\left(F_{2}\right)$ reached a scanty flowering in September of the same year and have later flowered copiously in Ig09 (June). Again the family $\mathrm{F}_{2}$ consists of only four specimens, but these are all quite alike in all characters and quite similar to the parent plant; they have given a fair number of fruits. Castration of $F_{1}$ (No. $286_{2}$ ) was repeated in I908 and out of the much more numerous offspring (No. 467) one plant reached flowering in September I909; it was also quite similar to the parent plant, and the same seems to be the case with the remaining ones, as far as can be judged from the vegetative characters alone.

We are thus allowed to conclude, that while the first generation $\left(\mathrm{F}_{1}\right)$ of $H$. auricula $\times$ aurantiacum is heterogeneous, the second generation $\left(F_{2}\right)$ is quite homogeneous and like the parent individual of $F_{1}$, in so far as it can arise at all.

b. As the experiment reported on only gave a few hybrid specimens, the same cross, with the same parent individuals, was repeated in 1907. 
One isolated corymb (two heads) of $H$. auricula was pollinated with isolated heads of H. aurantiacum (also from only one corymb). The fruits gathered were sown in April 1908 and produced a family of 29 individuals, most of which reached flowering in the autumn of the same year. They presented an astonishing variety or heterogeneity, and there were not two individuals completely alike and all (with perhaps one exception?) were hybrids. They varied with regard to the colour of the flowers, of which the annexed reproduction of coloured drawings on Plate 4 will give a better idea than long descriptions. The specimens in flower in autumn I 908 have been arranged on the plate after flower colour alone, forming a series from $H$. auricula to $H$. aurantiacum. Further, they varied with regard to the size and hairiness of the head; the number of heads; the length and hairiness of the scapes; the form, colour and hairiness of the leaves; the form and vigour of the stolons, e.t.c. No correlation between the variations of the different characters was discovered.

Some heads of the autumnal flowering specimens were isolated. In 12 specimens all the fruits were empty, but in 5 specimens at least some few fruits were apparently full and were sown in the spring of I909. Four of these gatherings have germinated and produced a few plants of $F_{2}$ which, however, owing to the bad summer, did not reach flowering in the same year, and about which I can say nothing more than that the rosettes of each set seem to be homogeneous.

In the winter 1908-09, unfortunately, 7 of the 29 plants of $F_{1}$ died. Among the rest, heads of several individuals were isolated in the summer of $19 \circ 9$ and with similar result as in the preceding year, most of them producing only empty fruits. Some experiments of crossing the hybrids with the parents also gave only empty fruits, but these experiments must necessarily be repeated.

The hybridization experiments hitherto carried out with $H$. auricula and $H$. aurantiacum, thus agree fully with the above-mentioned extensive experiments made by MENDEL. My experiments have the advantage that only one single corymb of both father and mother has been employed for the cross, so that is cannot be objected that the heterogeneity in $F_{1}$ depends on different father or mother individuals.

Thus we have substantiated in the cross $H$. auricula $\times$ aurantiacum an astonishing heterogeneity in $F_{1}$, and no correlation as to the characters mutually. Most individuals of $F_{1}$ are sterile, but a few of them bear some few fruits and these are even developed apogamically 
as in the father. With regard to the fertile $F_{1}$ individuals, they produce an $\mathrm{F}_{2}$ which is completely homogeneous and quite like the parent individual of $F_{1}$; this must no doubt be attributed to the apogamy. From another point of view, the origin of species by means of hybridization, we may be allowed to say that the cross $H$. auricula $\times$ aurantiacum can give rise to new forms or species, at once quite constant.

\section{H. excellens $\times$ aurantiacum.}

a. As mentioned in my paper of Igo6 (p. 239), in June Ig04 I castrated some heads of the many-headed $H$. excellens (related to H. magyaricum N. P.) and isolated others, and at the same time pollinated some heads of another corymb of the same individual with $H$. aurantiacum. The castrated and the isolated heads gave rise to a new, apogamically developed generation, while the result of the crossing was 20 individuals of pure $H$. excellens and 6 hybrids. These 6 were all different to one another, but the differences in characters were almost always within the range of the characters of the two widely different parents. Most prominent was the difference in sexuality; the mother plant, H. excellens, is purely female, while the father plant, $H$. aurantiacum, is hermaphrodite, and some of the hybrids followed the mother, others the father. The characters of the 6 hybrids can be described briefly in the following way:

No. $46_{1}$. Vegetative part comparatively weak, and development of stolons much poorer than in either of the parents; hermaphrodite; corolla pure yellow.

No. $46_{2}$. Vegetative part vigorous; very similar to the mother, but more robust; female; corolla yellow as in the mother, but the head a little larger and with dark, more hairy involucre.

No. $46_{3}$. Vegetative part vigorous; similar to the mother, but more robust; female; corolla orange-yellow with a red stripe on the underside and red teeth; head as in $46_{2}$.

No. $46_{4}$. Vegetative part vigorous; rather intermediate; hermaphrodite; corolla yellow-orange-red with red underside and red teeth; head as in $46_{2}$. (Figured in the paper of 1906 as fig. 5.)

No. $46_{5}$. Vegetative part weak; development of stolons rather poor; hermaphrodite; corolla nearly as $46_{4}$, perhaps a little nearer to the father; quite sterile, died after first flowering.

No. $46_{6}$. Vegetative part weak; leaves of the rosette narrower than in the parents. Died in the winter of $1906-07$ without any flowering. 
These short descriptions will show how different the members of this family were. It is worth noticing that No. $46_{1}, 46_{5}$ and $46_{6}$ are vegetatively, especially with regard to the development of stolons, weaker than both the parents. Most frequently hybrids are said to be vigorous and often more vigorous, than the parents.

Only the four first enumerated specimens have kept under cultivation, and I have followed them through several generations.

$$
\text { I. H. excellens } \times \text { aurantiacum, No. } 46_{1} \text {. }
$$

The primary hybrid, $F_{1}$, died in $x_{905}$, after bearing fruits under isolation. Hence arose an $F_{2}$ of 3 individuals, all of which were vegetatively weak, without regular development of stolons and with pure yellow hermaphrodite flowers, thus quite like the $F_{1}$. In one of these individuals castration, as well as isolation, was made with respectively 4 and 3 heads, but the development of full fruits was very slight. Thus the $F_{3}$, which arose from sowing of these fruits, consisted of only 4 and 8 individuals, all alike und all like $F_{1} . F_{4}$ came out in I909, but did not reach flowering.

We thus have full constancy in the second and the third hybrid generation, in so far as the small number of developed fruits permits us to judge.

2. H. excellens $\times H$. aurantiacum, No. $46_{2}$.

The primary hybrid from 1904 is still alive. Without isolation seeds were got, which gave rise to an $\mathrm{F}_{2}$ of 25 individuals, all alike and like $F_{1}$, and female. As this experiment was not exact, a corymb of the primary hybrid was isolated in 1906 , and from the gathered seeds there came 85 individuals of $F_{2}$, all alike and all like $F_{1}$, yet with the exception of one individual which had reddishly tinged leaves and scape. One corymb of this individual was isolated, and an $F_{3}$ of 38 individuals was produced, all alike and like $F_{1}$, i. e. without any reddish tint; nor was the $\mathrm{F}_{2}$-individual itself this year reddishly tinged. The reddish colour is consequently not inheritable, but is no doubt a result of bad conditions, most probably of drought, and was here most likely caused by ants, which, by establishing their nest round the base of the plant, let too much fresh air into the soil and perhaps also injured the roots.

In this hybrid also there is full constancy in the second and the third generation. 
3. H. excellens $\times$ aurantiacum, No. $46_{3}$.

The primary hybrid is still alive. With the first isolation (in I905) only one individual of $F_{2}$ was obtained; it was quite like $F_{1}$. Isolation was therefore repeated in I906, and now there came out an $F_{2}$ of 53. individuals which flowered in 1908. Out of these, 52 were homogeneous and quite like $F_{1}$, but one individual differed very considerably. This mutant is vegetatively weak and with slight development of stolons, with yellow corollas and with copious pollen, apparently hermaphrodite, while all the other individuals as well as $F_{1}$ are female 1 ). It resembles much No. $46_{1}$, but differs with regard to the colour of the corollas, being in the mutant orangereddish on the underside. Unfortunately it is quite sterile on isolation, which has been tried both in 1908 and Igog.

$\mathrm{F}_{3}$, sprung from the normal $\mathrm{F}_{2}$, was planted out in Igog, but did not reach flowering.

We have then here a case where the main part of the second generation of the hybrid behaves as in the two foregoing cases, but where suddenly an individual has come out which is a distinctly and easily recognisable mutant. It is not a retrograde step to any of the parent species, but a new combination of their characters. It is a pity that it is not possible to work further with this mutant, as it seems quite sterile.

4. H. excellens $\times$ aurantiacum, No. $46_{4}$.

From the primary hybrid, which is now dead, was got by isolation an $\mathrm{F}_{2}$ of 27 individuals and by castration II individuals, and all 38 specimens were quite homogeneous and like $F_{1}$. By isolation of one of the 27 individuals of $\mathrm{F}_{2}$ were obtained ro7 individuals of $\mathrm{F}_{3}$, and by castration of one of the II individuals of $F_{2}$ were obtained 98 individuals; altogether, $\mathrm{F}_{3}$ consisted of 205 individuals, all alike and like $F_{1}$. Still, several of them were reddishly tinged and somewhat weaker than the others, but this must no doubt be explained in the same way as above. $\mathrm{F}_{4}$ was planted out in I909, but did not reach flowering.

1) It is not unknown that a mutant differs from its parent with regard to sexuality; e. g. Oenothera lata, one of DE VRIEs's classical mutants, is purely female while O. Lamarckiana is hermaphrodite, See R. R. GATES (1907a, 1907 b, 1909a) who has worked out its behaviour thoroughly. 
In this hybrid there is thus full constancy with regard to the second and the third generation, just as in the two first hybrids of H1. excellens $\times$ aurantiacum.

b. In the summer of Ig04 another cross with H.excellens and H. aurantiacum was made, using another specimen of $H$. aurantiacum. The result was, besides some pure H. excellens, one hybrid (No. 48a) which was near to the mother in characters. It differed in having somewhat larger and more dark-hairy heads and, at least, in some of the outer yellow corollas, a distinct, though often small and feeble red stripe on the underside. Like the mother the hybrid was purely female. It is still alive.

By castration was obtained only one individual of $F_{2}$ and by several isolations altogether $I_{3}$ individuals, all alike und like $F_{1}$. By means of isolation a third generation, $\mathbf{F}_{3}$, consisting of 106 individuals came out, all alike, still with individual differences with regard to the intensity of the feeble reddish tint on the underside of the marginal corollas. As in the first reported cross here also constancy in the later hybrid generations rules.

c. A cross between $H$. excellens and $H$. aurantiacum, made in I907, produced one hybrid, which quite resembled the just mentioned No. $48 \mathrm{a}$, but has not been studied further.

All the experiments here reported on show that the crosses between $H$. excellens and $H$. aurantiacum give a heterogeneous $F_{1}$, but that each individual of these primary hybrids is able to produce a quite constant and homogeneous offspring, if it is not quite sterile. The explanation of this constancy is probably that the offspring comes from seeds developed apogamically. The one mutant in $F_{2}$ of No. $46_{3}$ is hitherto an isolated fact, which does not allow far reaching conclusions, still it shows that also apogamic plants are able to mutate.

The little table (IV) given here recapitulates the number of hybrid offspring produced during the experiments:

$$
\mathrm{T} a \mathrm{~b} l \mathrm{e} \text { IV. }
$$

Number of Hybrid-Offspring of Hieracium excellens $>$ H. aurantiacum.

\begin{tabular}{c|c|c|c|c|}
\hline & $F_{1}$ & $F_{2}$ & $F_{3}$ & \\
\hline $46_{1}$ & I & 3 & I2 & \\
$46_{2}$ & I & I IO & 38 & 1) To these is to be added a single mutant. \\
$46_{3}$ & $\mathrm{I}$ & $\left.5^{1}\right)$ & - & 1) To \\
$46_{4}$ & $\mathrm{I}$ & $3^{8}$ & 205 & \\
$48 \mathrm{a}$ & $\mathrm{I}$ & $\mathrm{I}_{4}$ & 106 &
\end{tabular}


Several experiments of crossing the hybrids with the parent species have hitherto given no results of interest, the offspring always being like the mother plant, i. e. the offspring have always been produced apogamically, the crossing being quite ineffective. The experiments made may just be enumerated:

a. H. excellens $>$ [excellens $\times$ aurantiacum, No. $\left.46_{4}\right]$. Result: 3 pure $H$. excellens.

b. H. [excellens $\times$ aurantiacum, No. $46_{3}$ ] $\times$ aurantiacum. Result: I9 individuals, like No. $46_{3}$.

c. H. excellens $\times$ [excellens $\times$ aurantiacum, $\mathrm{F}_{2}$ of No. $\left.46_{4}\right]$ Result: 29 pure $H$. excellens.

\section{II. excellens $\times$ pilosella.}

By crossing, in $1904, H$. excellens with $H$. pilosella there came out, besides some pure $H$. excellens, 8 hybrid specimens, which did not behave quite as the hitherto mentioned hybrids, being indeed somewhat heterogeneous, but not in the same degree as these.

Here follows a list over this family of hybrids with characteristics:

No. $50_{1}$. Vegetative part vigorous; well developed stolons; the corymb with long scape and many subumbellate heads of which some indeed on long stalks issuing from the lower part of the scape; on the whole rather near $H$. excellens, but a little coarser and lower and the heads a little larger; female.

No. $5 \mathrm{O}_{2}$. Much as the preceding and also female, but perhaps. still a little nearer $H$. excellens.

No. $5^{0_{3}}$. Much as the preceding, also female. (A not typical, slender and few-headed corymb from an autumnal flowering has been figured in I906 as fig. 6.)

No. $5 \mathrm{O}_{4}$. Low and nearer to $H$. pilosella; the corymbs with few, distant and long-stalked, large heads; hermaphrodite; yet the rosette leaves resemble those of $H$. excellens.

No. $5^{0_{5}}$. Much as the foregoing; hermaphrodite.

No. $5^{\circ}$. Died without flowering, but was an evident hybrid.

No. 50 . Also died without flowering.

No. $50_{8}$. Tall and vegetatively vigorous with subumbellate rich corymb on a long scape; resembles $5 \mathrm{O}_{2}$ and $5 \mathrm{O}_{3}$, and female.

If we do not consider the two hybrids that died before flowering, we have six individuals left, and of these the four were fairly, but not absolutely, alike, and near $H$. excellens from which they differed 
in being coarser and somewhat lower in the corymb-scape and with slightly larger heads, all characters from $H$. pilosella. The two others (No. $5 \mathrm{O}_{4}$ and $5 \mathrm{O}_{5}$ ) were also much alike and near $H$. pilosella, but still greatly differing by the corymb-scapes having several (not solitary), long-stalked heads, whose size was a great deal under that of the heads of $H$. pilosella. They were hermaphrodite, while the four other individuals (sub-excellens) were female.

All 6 individuals have in common that their power of fruiting is very slight. Notwithstanding repeated experiments in different ways $I$ have not yet succeeded in getting more than a few apparently full fruits in any experiment and in most of them no full fruits at all. Thus, after isolation $I$ have got only a single $F_{1}$-individual of $50_{2}$, of $50_{3}$ and of $50_{8}$ each, - that is of three individuals of the sub-excellens-group; these $F_{2}$ individuals have all been like their $F_{1}$.

An experiment of crossing $50_{5}$ with the mother parent ( $H$. pilosella) gave rise to only three individuals which were different from one another and all three different from their $F_{1}$-parent. One (No. 406 ${ }_{1}$ ) was, at least apparentiy, pure $H$. pilosella, and consequently a complete segregation must have taken place. The other two showed hybrid characters; one of them (No. $406_{3}$ ) was rather near the mother (the primary hybrid), still somewhat nearer $H$. pilosella, and the third (No. $406_{2}$ ) was very peculiar; it had leaves narrower than those of both parents, long thin stolons, mostly approaching the excellens-type; the corymb bore long branches with few flower-heads, much as the inflorescences on the stolons of $H$. excellens. Unfortunately both the last named plants were weak and died in the winter after the first flowering; they seemed to be quite sterile.

The cross between $H$. excellens and $H$. pilosella has thus given only the following result: the primary hybrid is heterogeneous, but less than in the other crosses, being nearly dimorphous ${ }^{1}$ ). All the individuals of $F_{1}$ are nearly sterile, the few individuals of $\mathrm{F}_{2}$ point to constancy, while the poor experiment of back-crossing may be said to show segregation.

On the whole, this hybrid combination seems to be unfavourable as a subject of experiment. It has therefore not been used so much for experiments, as interest in its peculiar behaviour would merit.

If we sum up the result of all the hybridization experiments hitherto made, we get the following conclusions:

1) Such cases H. DE VRIES (1907, 1908) has named Twin-hybrids. 
I. It seems natural to place in one group $H$. pilosella $\times$ aurantiacum and $H$. excellens $\times$ pilosella, consequently both combinations, with $H$. pilosella as the one parent plant ${ }^{1}$ ). In this group the $\mathbf{F}_{\mathbf{1}^{-}}$ generation is (under isolation) wholly or nearly without power of forming fruits capable of germination, - consequently self-sterile. By crossing the $F_{1}$ with one of the parents, an $F_{2}$ of few individuals has been produced which seems to segregate.

2. Opposed to this stands the other group where $F_{1}$ is rather fertile by isolation and where $F_{2}$ and $F_{8}$ show full constancy. The type of this group is $H$. excellens $\times$ aurantiacum; still perhaps No. $46_{1}$ and the mutant of No. $46_{3}$ belong to the first group.

The hybrid $H$. auricula $\times$ aurantiacum must probably be divided so that most individuals of $F_{1}$ belong to the first group, while some few belong to the second.

The second group is of more interest, for here an experimental proof is given that by hybridization between far distant species within the subgenus Pilosella new forms can arise which are fully constant and which behave as new species.

III.

\section{Apogamy and its Relation to Polymorphism.}

From the researches of MURBECK (I904), KIRCHNER (I905) and especially from the cytological investigations of ROSENBERG (Ig06, 1907) on the apogamy of Hieracium, it has been shown that the development of the non-fertilized embryo goes on in different ways, partly by true apogamy, partly by the curious apospory discovered by ROSENBERG. We shall not enter into the cytology at great length, but only mention that the embryo is always developed from an "egg-cell" which has the vegetative (unreduced) number of chromosomes; this form of apomixis is by H. WINKLER (1908, p. II) called somatic parthenogenesis. Still, I prefer to maintain the terminology of STRASBURGER (I904, p. II3 and p. II8), according to which our case falls under apogamy, as we speak of parthenogenesis only in the case where the egg-cell has the reduced number of chromosomes and yet develops into an embryo without fertilization (H. WINKLER's

1) As regards the dimorphism of $H$. excellens $\times$ pilosella, it is worth recalling that MENDEL has produced a great number of hybrids between $H$. auricula (as mother) and different races of $H$. pilosella, and that these hybrids of $F_{1}$ have been like one another (CORRENS 1905, p. 243). It seems thus that $H$. pilosella hybrids behave in a different way from those in which $H$. aurantiacum is father parent. 
generative parthenogenesis); this has hitherto not been found in the phanerogams.

The definition I gave for apogamy in my paper of I9o6 was perhaps rather indistinct; it runs: "that it comprehends all cases where a plant gives seeds, developed from the ovules, without fertilization, whether the egg-cell or other cells of the embryo-sac or a cell from the nucellus are the starting point" (l. c., p. 233, footnote). The last-named case was intended to correspond to the apospory which RosEnBERG had then found. Now, I shold prefer to use the following short definition, employing the terminology given by H. WINkLER. A pogamy is the apomictic development of a sporophyte from one or several cells of the gametophyte, assuming that the number of chromosomes is unreduced. Thus I include in apogamy both WINKLER's apogamy and his somatic parthenogenesis, making no sharp distinction between the apomictic development of the "vegetative egg-cell" and that of the other gametophyte cells, but considering the former case only as a special case of apogamy.

H. WINKLER in his excellent account of parthenogenesis and apogamy in plants (1908) has put together all the then known cases of apogamy in its different forms. Since then, several new cases have been found, especially with regard to the phanerogams. In the following I restrict myself to the phanerogams and the considerations expressed apply only to these and among them especially to the dicotyledons, with the apogamy of Hieracium as main point of view.

A list of the hitherto known cases of apogamy (in my sense) among phanerogams will have the following appearance:

Monocotyledones.

Triuridaceae: Sciaphila nana B1. (V. A. PoUlSEN, I905).

Burmanniaceae: Burmannia coelestis Don. (A. ERNST, I909).

Thismia clandestina Miq. (K. MEYER, I909).

Thismia javanica J. J. Sm. (A. ERNST and Ch. BERNARD. I909).

Dicotyledones.

Saururaceae: Houttuynia javanica Thbg. (SHIBATA and MIYAKE, I908).

Moraceae:[?] Ficus hirta Vahl, and perhaps other species (TREUB. I902), 
Urticaceae:[?] Elatostema acuminatum Brogn. (TREUB, I905). Elatostema sessile Forst. (Modilewsky, I908).

Menispermaceae:[?] Disciphania Ernstii Eichl. (ERNST, I886). Ranunculaceae: [?] Thalictrum Fendleri Englm. (DAY, I8g6). Thalictrum purpurascens L. (OVERTON, I902).

Rosaceae: Alchimilla, sect. Eualchimilla (MURBECK, I897, I9or) Rosa glauca Vill., subsp. Rosa virentiformis Matss. $\}$ (E. LUNDSTRÖM, Igo7).

Thymelaeaceae: Wikstroemia indica L., Buitenzorg (H. WINKLER, Ig04).

Balanophoraceae: Balanophora elongata Bl. (TREUB, I898). Balanophora globosa Jungh. (LOTSY, I899).

Helosis guyanensis Rich. (CHODAT and BERNARD, Igoo).

Compositae: Antennaria alpina (L.) Gärtn. (O. JUEL, I898, I900). Antennaria fallax Greene | (LEAvitT and Antennaria neodioica Greene $\}$ SPALDING, I905). Taraxacum, all species examined (RAUNKIAER, Ig03).

$\left.\begin{array}{l}\text { Hieracium, subgen. Pilosella } \\ \text { Hieracium, subgen. Archieracium }\end{array}\right\}$ nearly all species, (OSTENFELD and RAUNKIAER, I904; OSTENFELD, Ig06).

It will be seen that the apogamy appears here and there in the families of the phanerogams without relation to their systematic position or affinities; still it is noteworthy that it is so common in the young family of Compositae, which must be supposed to be in its full vigour. There is therefore no reason for setting apogamy in any communication with degeneration.

The quoted cases of apogamy are not all certain, at least the cytological evidence is still wanting for several of them. Among the uncertain ones is Ficus, and among the imperfectly examined are Sciaphila, Thismia and the North-American Antennaria's. Quite unexamined in cytological regard are Disciphania and Thalictrum Fendleri. These two and Ficus are omitted in the following considerations.

Now, if we look at the list, bearing this in mind, we find the peculiarity that not all the species within a gen us are apogamic; some are normally sexual. This applies to all the genera named of Compositae, as RosenberG has lately (rgog, p. $\mathrm{I}_{5} \mathrm{I}$ ) shown that a 
species of Taraxacum (T. confertum Dahlst.) must be supposed to be sexual. Taraxacum was hitherto taken to be the only example of a wholly apogamic genus. Further, it applies to Elatostema, Thalictrum, Wikstroemia, Alchimilla, Rosa and Balanophora. We do not know the condition in Thismia, Burmannia, Sciaphila and Helosis - all saprophytic or parasitic plants - as cytological investigations have not yet embraced other species of the genera named than the apogamic ones here enumerated. Lastly, it has to be added that Houttuynia is a monotypic genus.

Another noteworthy fact with regard to apogamic plants is that comparatively many apogamic plants are pale, chlorophyllwanting saprophytes or parasites, viz.: Sciaphila, Thismia, Burmannia coelestis, Balanophora and Helosis. Whether this fact may be of some importance or is casual, is difficult to decide at present. A. ERNST and ED. SCHMID are no doubt right in saying in their paper on the normally sexual Rafflesia patma Bl. (Igog, p. I84): "so wird man auch bei anderen Parasiten in der Annahme von Beziehungen zwischen Reduktion der vegetativen Organe und Anomalien in der Embryosackentwicklung mit oder ohne Apogamie vorsichtig sein müssen."

The list shows, however, a third fact worthy of interest and which has already called forth many considerations, that is, the evident relation of apogamy to polymorphism. We must here except the pale. saprophytes and parasites, and further Houttuynia, in which we know nothing about polymorphism. But with these exceptions all the hitherto thoroughly examined cases of apogamy (in the dicotyledons) fall within polymorphic genera, that is, genera in which at the present time an intense evolution of species is supposed to be taking place. The polymorphism in Alchimilla, Rosa, Taraxacum and Hieracium is well known. In Antennaria we find polymorphism in North America (not in Europe), in Thalictrum both in North America and in Northern Europe; Elatostema is a "critical" genus. Finally, H. WINKLER (I908, p. I47) and STRASBURGER (I909, p. 85-87) have shown that Wikstroemia indica is a polymorphic species, of which for the present only the examined "race" from the Buitenzorg Gardens has been proved to be apogamic, while others seem to be normally sexual. Thus it cannot longer be used as an instance of "Apogamie ohne Polymorphismus" (TIschler, I908, p. I39)1).

1) It would also agree very well with the relation of apogamy to polymorphism, if R. R. GATES (Ig09b) is right in his new supposition, that Oenothera lata, one of 
The first who touched upon this apparent relation of apogamy to polymorphism, was SV. MURBECK, who as early as I897 (p. 277) - he accentuates it a little too strongly later (I904, p. 295) has intimated that for the Alchimilla's there must be a certain relation between the constancy shown by the apogamy and the polymorphism. His words, however, are very vague. Having mentioned that the reason for the great constancy of the Alchimilla species has to be sought in the apogamic development of the seeds, which is really to be considered as a kind of layer-formation, he says that in a later detailed cytological investigation he will perhaps also have occasion to express himself "on a question at present obscure, how the polymorphism now ruling within the genus has come about. For that, however, is required an exact knowledge of the geographical distribution of the forms" 1 ).

Somewhat more fully and decisively RAUNKIAER expresses himself (Ig03, p. I36-r38) about the Taraxacum species. From the fact that all the species examined by him, which have widely different geographical distributions, are apogamic, he concludes "that the power of forming seeds without fertilization has originated in Taraxacum before this genus was split into many species and that the existing species have originated without any fertilization or crossing" ${ }^{2}$ ). If this conclusion is right, he thinks that in Taraxacum we have a genus which may be of importance for the study of the origin of species, and that future investigations on the species and their geographical distribution will contribute to the solving of the question, whether the origin of species has been occasioned in the Lamarckian way or in the Darwinian way (incl. that of mutation).

In his paper on apogamy in Taraxacum and Hieracium MuRBEck (I904) - as already mentioned - comes back to this problem,

the mutants of Lamarckiana, is partly apogamic, "though only in a small percentage of cases". But "this indication of apogamy in $O$. lata of course requires to be substantiated by a more detailed study".

Mrs. R. HaIg Thomas has recently (I909) published a short paper on „Parthenogenesis in Nicotiana", and probably we have here a new case of apogamy, which agrees well with the relation-theory, as Nicotiana is a critical genus.

1) "om ett annat för närvarande dunkelt spörsmål, huru den nu rådande polymorfismen inom släktet en gång kommit til stånd. Härför erfordras emellertid en noggran kännedom om formernas geografiska utbredning".

2) "at Evnen til at danne Kim uden Befrugtning er opstaaet hos Taraxacum, för denne Slaegt er blevet spaltet i flere Arter, og at de existerende Arter er opstaaet, uden at Befrugtning og Krydsning har spillet nogen Rolle". 
and says, that the geographical distribution of the Scandinavian Alchimilla species has not been able to contribute to the solving of the problem, as they have proved to be widely distributed in Europe ${ }^{\mathbf{1}}$ ). He then says: "Ganz anders verhält sich Hieracium. Betreffs dieser Gattung weiß man gewiß - besonders infolge der sorgfältigen und eifrigen Forschungen DAHLSTEDT's und seiner Schüler -, daB Hunderte von kleinen Arten auf die Skandinavische Halbinsel beschränkt sind und da $B$ eine Menge von ihnen nur kleinere Teile derselben bewohnen. $\mathrm{Da}$ unter den übrigen Phanerogamen Skandinaviens Endemismen äußerst selten sind, weil ja die ganze Flora der Halbinsel nach der Eiszeit eingewandert ist, so $\mathrm{mu} B$ man annehmen, daß eine große Menge Hieracien in einer verhältnismäßig sehr späten Zeit daselbst entstanden sind und da $B$ eine lebhafte Artbildung sozusagen vor unseren Augen stattfindet. Dagegen ist man geneigt, die Apogamie bei dieser Gattung als eine Erscheinung von verhältnismäBig hohem Alter zu betrachten, da sie innerhalb verschiedener Gruppen und auch bei der Untergattung Pilosella aufgewiesen ist. Ist diese Auffassung die richtige, so würde daraus folgen, da $B$ eine Menge Hieracien aus Formen, die selbst apogam waren, entstanden sind und noch immer entstehen. $\mathrm{Da}$ aber so beschaffene Formen nicht individuell variierend $\sin ^{2}$ ), so muß man annehmen, da $B$ die jetzt lebenden apogamen Hieracien aus inneren und unbekannten Ursachen und sozusagen sprungweise entstanden sind." To these interesting suppositions, which I have quoted in extenso, he adds, however, the following weakening words: "Von der Richtigkeit dieser Folgerung bin ich doch selbst keineswegs recht überzeugt, da die wichtigste Prämisse, nämlich die Annahme des hohen Alters der Apogamie, wie wahrscheinlich sie auch sein mag, doch nicht auf hinlänglich sicherem Grunde ruht. Um zu einem solchen zu gelangen, sind jedenfalls mehr umfassende Untersuchungen vonnöten als die bisherigen". I think that the investigations made since then are all in favour of MURBECK's suppositions and go against the reservation so strongly accentuated by himself.

In the meantime, both MURBECK'S and RAUNKIAER'S reflections touch more upon the question of the origin of species and its relation to apogamy, and not so much upon the question if there is a causality

1) The just published monograph of the northern Alchimillae by HaRALD LiNDBERG (1909) shows that there are considerable and very inceresting differences in the distribution of the species, pointing to quite different ways of immigration.

2) This is scarcely correct, see later. C. H. O. 
between apogamy and polymorphism, and the question probably connected herewith, the origin of the apogamy.

STRASBURGER is the first who has raised this problem particularly. In his interesting paper on the apogamy in Alchimilla (I904), he has rather extensively treated the question of the relation of apogamy to polymorphism. By examination of some Rubi and Rosae he has shown that they were normally sexual, so that we dare not speak of an absolute connection between the two phenomena. Still, he supposes that in the polymorphic Eualchinillae "übermässige Mutation" has caused the sexual abnormality which here also becomes apparent by the degeneration of the pollen. His opinion is the following (1. c., p. I52): “Wenn aber übermäBige Mutation die Sterilität fördern sollte, so würde sie das Fortbestehen der betroffenen Art gefährden. Apogame Fortpflanzung stellt sich als Aushilfe in bestimmten Fällen ein, doch auch sie dürfte Rettung wohl nur für eine phylogenetisch begrenzte Zeitdauer bringen, da die apogame Art aller der Vorteile verlustig geht, welche die geschlechtliche Fortpflanzung mit sich bringt". In his summary (p. 160) he repeats the same opinion. It seems then that he thinks the commencement of the period of mutation to be prior to the apogamy and the latter called forth by excess of the mutation. In Eualchimilla he supposes that the mutation

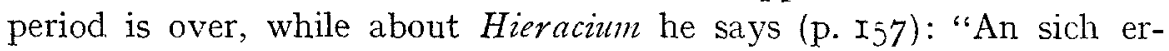
scheint die Möglichkeit der Fortdauer der Mutation bei Hieracien nicht ausgeschlossen. Denn es ist durchaus nicht bewiesen, da $B$ diese mit Eintritt des Geschlechtsverlustes ihr Ende nehmen müsse", and here he refers to the polymorphic alga genus Caulerpa, in which no sexual propogation has been found, and to the inheritable bud-mutation found by R. v. WeTtSTEIN (I904) in Sedum reflexum. In my opinion the investigations on the Hieracia are rather to be interpreted in the following way. The presence of apogamy fixes the new mutants, which in a normally sexual genus would perhaps disappear by crossing with the parent species; but mutation (polymorphism) and apogamy cannot be considered as cause and effect.

After STRASBURger another German botanist G. TISCHLER has taken up the question in his cytological studies on hybrids (Ig08), taking a special interest in the slight production of pollen, so frequent in many polymorphic genera, a fact which he connects with the apogamy. He says (1. c., p.138): "Es erscheint woll dabei sicher, daß nicht die Apogamie das Primäre, die Pollenreduktion das Sekundäre ist, sondern daß gerade umgekehrt erstere sich einfand. nachdem 
eine normale Befruchtung nicht mehr möglich war," and further (p. I46): „Apogamie hat sich als "Aushilfe" auf die Mutation und Sterilität des Pollens eingestellt und ist nicht das Primäre und die Pollenobliteration das Sekundäre." He thus expresses himself much more explicitly than STR.ASBURGER. I think that these considerations are untenable, as e. g. Hieraciun aurantiacum is a typical apogamic species, which must be admitted already from MENDEL's experiments (CORRENS I905, p. 240), at least compared with mine, but it has good pollen able to fertilize other species, as shown by the hybridization experiments. This has been pointed out by CORRENS (1905, p. 249), and both O. RosenbeRG (Igo9, p. I60) and H. WiNkLER (I908, p. I36) have used this fact as an objection against STRASBURGER and TISCHLER.

H. WINkLER again, as a further objection, points to Thalictrun purpurascens and Taraxacum - both apogamic and with apparently good pollen -, in which, without proof certainly, he supposes that the pollen must be able "eine wirksame Befruchtung auszuführen". WrNkLER himself is very cautious and weighs all possibilities for an explanation of the origin of apogamy, as appears clearly from his summarizing words, viz.: "Nach dem gegenwärtigen Stande unserer Kenntnisse können wir also über die Faktoren, die phylogenetisch die Einführung der habituellen Parthenogenesis oder Apogamie bewirkt haben, ebensowenig etwas Sicheres aussagen als über die Natur der Reizvorgänge, die jeweils im Verlauf der Ontogenese sie auslösen" (p. I38). In his last chapter he advances the possibility, that in strongly mutating forms there is greater probability for the arising of a mutant, which is apogamic or has apogamic tendencies, sooner than in not-mutating forms, and as in such cases the "ausgleichende Moment" of the fertilization is absent, the mutant can keep constant. Here he refers to MURBECK's explanation of the remarkable constancy of the Eualchimillac. Still, this view implies, in his opinion, the following supposition, "daB parthenogenetisch oder apogam gewordene Pflanzen nicht mehr mutieren oder variieren können" (1. c., p. I48). I do not see that this supposition is necessary or even correct, and here my opinion agrees with that of STRASBURGiz quoted above.

Quite recently O. ROSTXBARG (IgOg) has put together the hitherto known "Tatsachen" about apogamy. He points out the correlation between apogamy and a great number of chromosomes, in contrast to, most frequently, half the number in the non-apogamic species within the same genus. He discusses the possible causes of apogamy and, as mentioned above, refers among other things to the fact that 
apogamy does not originate as a reaction against sterility of the pollen (the case of $H$. amantiacum).

Taking all the quoted opinions together I regard the above given sentences of H. WINKLER as a good expression for the present position of the question with regard to the origin of apogamy.

I may sum up my views on these matters in the following way, bringing together what the investigations, in my opinion, have proved:There is, at least with regard to the dicotyledons, an evident relation of apogamy to polymorphism, but it is not allowable to draw any conclusion as to causality between them or as to the age of the apogamy.

The supposition of STRASBURGER and TISCHLER, that apogamy is a secondary thing while degeneration of pollen is primary, is not tenable.

WINKLER's supposition, too, that apogamic plants do not vary or mutate, is scarcely correct.

As to Hieracium it must even be considered unlikely that the species now existing have originated before apogamy arose. Nothing hinders the supposition that new species can originate from apogamic parents, and we may compare this case with the inheritable bud-mutations which have been studied, e. g. by WETTSTEIX (I904) and W. JOHANNSEN (I908). The results of my hybridization experiments, mentioned in the earlier part of this paper, point in that direction. It has there been proved that a mutant has arisen in $\mathrm{F}_{2}$ of an apogamic hybrid; - certainly only one specimen.

The hybridization experiments show further that hybrids are able to propagate apogamically and then are constant. This makes it allowable to conclude, $I^{0}$ that within Hieracium the evolution of new species goes on coincidently with the existence of apogamy; $2^{\circ}$ that the new species reach constancy at once just because of the apogamy $\left.y^{1}\right) ; 3^{0}$ that the polymorphism is correlated to the apogamy in such a manner only that apogamy, through the constancy of the species, apparently furthers the polymorphism.

1) Almost the same conclusion has been drawn by I. v. WetTstern (1904, p. 517), who sitys, "Ls ist leicht verständlich, daß bei solchen Pflanzen [Alchimilla and Hieracium], bei welchen die Rückführung in den ursprünglichen Typus durch Kreuzbefruchtung ausgeschlossen ist, jede auftretende Mutation sofort fixiert werden und - insofern die so entstehende Pflanze nicht unzweckmässig ist - zur Neubildung einer Art führen kann. Der Polymorphismus solcher Gattungen ist dann - zum Teile wenigstens - direct cer Ausdruck der Mutationsfähigkeit derselben." 
IV.

The Importance of Hybridization for the Origin of New Species, with special regard to Hieracium.

It would far exceed the scope of the present paper to give a full account of the question about the importance of hybridization for the origin of species. Much has been said pro et contra in this matter, which in the last decennium has entered upon a quite new phase by the general acknowledgment of the fundamental importance of the Mendelian segregation, both in the animal and the vegetable kingdom.

In the following pages I restrict myself to some remarks - with the Hieracia as starting point - on the question what views are now applicable to this interesting and important matter.

We find the only detailed remarks on the importance of the Hieracium hybrids for the origin af new forms in the monumental work by C. VON NAGELI and A. PETER on the Piloselloideae of Central Europa (I885) and in the detailed paper by A. PETER on the hybrids of the Piloselloideae (I884). A most remarkable thing, regarding our question, in these papers is to see how little these authors have understood the value of MENDEL's experimental researches, and this seems still more extraordinary when we think of the letters from MENDEL to NAGELI, published posthumously by CORRENS (I905), letters which have so often been quoted in the preceding pages and which contain much more copious information on Hieracium hybrids than MENDEL's own short account of I87o. The importance of MENDEL's researches has evidently not become clear to the eminent botanist NAGELI; nor to W. O. FOCKE, who in his meritorious book "Die Pflanzenmischlinge" (I88r) only briefly enumerates the hybrids published by MENDEL ( 1870 ), and, later on, incidentally mentions Hicracium as an exception from one of his rules ("Sätze"), viz.: that all individuals of the first hybrid generation are "einander in der Regel völlig gleich" (1. c., p. 469).

The papers of NAGeli and PETER, mentioned above treat only of the subgenus Pilosella. The authors point out that by hybridization is "im allgemeinen keine neue Erscheinung hervorgebracht, weil die Bastarde lediglich eine Mischung der elterlichen Merkmale repräsentieren" (I885, p. 63). The heterogeneity of the first hybrid generation $\left(F_{1}\right)$ is well known to them, and they even give an explanation of it, viz.: 
"Diese Thatsache wird erklärlich, wenn man bedenkt, daß die Merkmale der beiden Eltern mit ihrem ganzen Formenkreise aus den Bastard vererbt werden, und daß demnach unter günstigen Umständen der Formenkreis des Bastardes ein beträchtlich weiterer sein kann, als der jeder Elternsippe eigene" (1. c., p. 63), - an explanation which, in my opinion, does not say anything. Besides, they attribute to the hybrids remarkably small importance for the evolution of the genus: "Bastarde sind vorübergehende Erscheinungen, ihre Befestigung ist nur ausnahmsweise möglich, fast nur dann, wenn ein Bastard zufällig isolirt wird und im Laufe der Generationen vermöge der allgemein geltenden ${ }^{1}$ ) Eigenschaft der Bastarde, nach und nach fruchtbarer zu werden, sich dauernd fortpflanzen kann" (1. c., p. 64). These considerations are, however, as hypothetical as those which the authors make on the slight chances of the hybrids for maintaining their existence when growing in company with the parents. As a proof of how difficult it is for hybrids to arise and of how little worth they are for the genus, the authors refer to the fact that in the Botanic Gardens of Munich, "unter den denkbar günstigsten Bedingungen" 1 ), when more than 2000 sets of Piloselloideae have been cultivated, during I7 years only about 70 hybrid combinations have arisen. In the opinion of the authors the hybrids are of value only when the relationship of the species (forms) among one another is to be decided on, - a rather theoretical value, if I may say so.

The hieraciologists of the present time have, on the whole, more confidence in the importance of the hybrids for the origin of species within this genus, at any rate with regard to the subgenus Pilosella ${ }^{2}$ ). But we find no investigations to prove the considerations about the matter, merely casual remarks here and there.

1) ? C. H. O.

2) Recently F. VoLLMANN (I909) has made some considerations on the matter. $\mathrm{He}$ is of the opinion that NäGELI and PETER have greatly underrated this speciesforming factor. After a sliort remark on MURBEck's discovery of apogamy in Hieracium and "die auf demselben Gebiete sich bewegenden Versuche von OSTENFELD uad RAUNKIAER" [sic!], he enumerates a whole series of cases, where he thinks it necessary to suppose, that the forms in question have arisen by hybridization, but he has made no experiments to prove these suppositions. Instead of these speculations, which may be correct enough, I should have preferred to see some experiments from him. Purely theoretical assertions have not much more worth than his introductory considerations, where among other things he says about "die direkte Bewirkung" [i. e. Lamarckismus], "daß dieser Art von Variation so manche Hieracium-Form ihre Entstehung verdankt, ist so gut wie sicher." 
In order to get better information, we must touch the great problem of the importance of hybridization for the origin of species in general and not restrict ourselves to a study of the papers on Hieracia, but we will not lose sight of the fact that our principal object is to answer the question with regard to the Hieracia. Generally taken, the question runs: Is hybridization of any importance as a species-producing factor in the Flowering Plants?

But before we can try to answer this question, we must briefly make clear what inheritance in hybrids means; in other words, we must learn what, at the present time, the workers in the problem of heredity say about the matter.

In his "Mutationstheorie" (vol. II, I902-03) and later in his lectures (Igo6), HUGO DE VRIES has copiously treated the problem. He distinguishes sharply between variety hybrids and species hybrids, just by reason of the supposed difference in inheritance ("balanced and unbalanced crosses"). In variety hybrids we find Mendelian segregation in force, while "es eine nicht unerhebliche Reihe von constanten Rassen giebt, welche durch künstliche Verbindung von zwei verschiedenen Arten entstanden sind, und sich im Laufe der Generationen in jeder Beziehung, höchstens mit Ausnahme der verminderten Fruchtbarkeit, wie gewöhnliche Arten verhalten" (Mutationstheorie, II, p. 73). He has himself produced a constant hybrid, Oenothera mutricata $\times$ biennis, which indeed has only a very limited fertility; moreover, he mentions as examples the hybrid Aegilops speltiformis, famous in the last century, and a hybrid Anemone silvestris $>$ magellanica produced by JANCZEWSKI, and calls attention to A. KERNER's merits for having emphasized the hybridization as an important factor in the origin of species in nature.

To be sure, the examples of natural hybrids, put forth by KERNER, cannot be said to be unassailable proofs, as we do not know the origin of these hybrids exactly, nor do we know whether the hybrids now existing are several generations old (consequently constant) or only the first generation which in course of time has propagated vegetatively; then all the examples are perennial plants. Nevertheless DE VRIES seems to agree with KERNER's supposition and to be inclined to consider species hybrids as important and as constant. It must not be forgotten, however, that by segregation through several generations new constant forms can also be produced, and that in the long run it is of no consequence whether the hybrid is constant 
at once as $F_{1}$, or only later becomes so ${ }^{1}$ ). But here we only speak about species hybrids which become constant in the first generation and in which no segregation takes place. DE VRIES has called this type the Hieracium type, as, referring to MENDEI's experiments, he took the Hieracium hybrids as the best known case of this form of inheritance in hybrids.

It appears, from what I have quoted here as well as from many other remarks of DE VRIES, that he considers this non-segregating type as rather widely spread, though only very few exact experiments have been carried out to prove its existence. A concurrent cause hereof is that species hybrids are so often quite sterile. A well known example is the Verbascum hybrids, which very easily arise both in nature and in Botanic Gardens, but which, as far as I know, are always quite sterile.

In contrast to DE VRIES, W. BATESON goes so far that he considers the non-segregating hybrids as rare exceptions. In his recent publication "Mendel's Principles of Heredity" (Igog) he deals with these exceptions in the first part of a particular chapter (XIV), which he begins with the following words "Of the various cases alleged to be exceptional, or declared to be incompatible with Mendelian principles, few have any authenticity. Several rest on errors of observation or of interpretation and some have even been created by a mistranslation or a misprint." The part of the chapter interesting to us here is "Crosses breeding true without segregation" (pp. 246-25I); it comprehends two sections, viz. A. Parthenogenetic cases, and B. Sexual Types.

The first section consists even of Hieracium, and BATESOx here briefly reports what has been known hitherto about the hybridization

1) Of this case we have an example in Rubus. B. Lidforss (1905. 1907) has by experiments shown that new species in this genus can arise both by nutation and by hybridization. As to the hybridization he has discovered the peculiarity that, while $F_{1}$ most frequently is homogeneous and oftenest intermediate, there arises after selffertilization a very polymorphous $F_{2}$ the heterogeneity of which, at any rate in part, must be supposed to be called forth by a mutation released by the hybridization. Also $F_{2}$ is inconstant, but in a less degree, and it seems as if constancy increases with the number of generations, so that constant new forms finally can be produced in this way.

As to the well known polymorphy in Rubus, it must be remembered that each individual has, practically seen, an indefinite lifetime and is able to form whole stocks by propagating only vegetatively. Thus both $F_{1}$ as well as the multifarious forms of $F_{2}$, etc. can respectively keep to the spot where ther have risen, even if they do not give constant offspring sexually. 
of the Hieracio and the pure-breeding of the hybrids. Together with this case he puts forward the remarkable fact that in certain Orchids a species, when fertilized with the pollen of different other species, still gives rise to an offspring which is completley like itself and shows no trace of the father parent. He considers this phenomenon, which he calls monolepsis, as "tantamount - as regards heredity - to parthenogenesis" (l. c., p. 249).

With regard to the sexual types $(B)$ almost all the known cases are, in BATESON's opinion, "open to the criticism made in the last section, that either actual parthenogenesis or monolepsis may be occurring" (p. 249), as far as the question is about plants. He quotes as the most trustworthy cases DE VRIES's above mentioned Oenothera muricata $\times$ biennis and JANCZEWSKI's Anemone silvestris $\times$ magellanica; but both these cases have in common that the fertility in the hybrid is very limited, which fact BATESON expressly mentions as weakening the convincing power of the cases. The same objection is made more emphatically by R. H. LOCK (Igog) who says that such cases do not prove anything, for perhaps the segregating factor is hidden in such a way that those germ-cells which should give the segregating individuals, are not functional. This objection is, in my opinion, valid. If then the vegetable kingdom does not show any incontestable case of true-breeding hybrids ${ }^{1}$ ), still some, though few, are found within the animal kingdom (mulatto, rabbits, butterflies), so that the existence of true cross-breeding cannot be denied, but we must clearly understand that it is the exception, and segregation the rule.

Even if BATESON's position is rather extreme, I think that this reaction is useful, especially as it makes clear to us what we know with certainty in this matter, - and that is very little, at least with regard to species hybrids.

In W. JOHANNSEN's "Elemente der exakten Erblichkeitslehre" (I909), published a few weeks before BATESON's book, similar points of view are held out. JOHANNSEN defines clearly and appropriately constant hybrids thus: "darunter versteht man ein Kreuzungsprodukt, $F_{1}$, das nicht spaltet" (p. 424), and also for him they are the exception, segregation the rule. In contradiction to DE VRIES, he - as

1) BAteson does not seem to know a paper (written in Swedish) by T. HedLund (1907), according to which a Malva hybrid (M. parviflora $\times$ oxyloba) seems to be quite fertile and constant in its offspring and still to have full fertility, but the experimental method of Heduund is perhaps not quite indisputable. 
also BATESON (rgog, p. 285) - means, that there is no settled difference between segregating variety hybrids and non-segregating species hybrids, and here I quite agree with these authors.

JOHANNSEN reports briefly the main points of my investigations on the Hieracia which I had placed at his disposal for this purpose, and points out, that: "diese Sache eine große Bedeutung haben kann für das Entstehen neuer Biotypen" (p. 425), but that we are still only at the beginning of the investigations. A little later he comes back to the constant Hieracium hybrids and says: "Es sind eben gleich als $F_{1}$, neue Rassen oder Species gebildet. Denn diese Biotypen verhalten sich ja wie homozygotische Organismen - ja sie sind es wohl eigentlich" (p. 437), - sentences with which I fully agree. Moreover, the investigations have now confirmed JoHANnsen's supposition in the following sentence, viz.: "Inwieweit das Nichtspalten, wie es bei den S. 425 erwähnten Ostenfeld'schen HieraciumBastarden wohl der Fall ist, oft mit Apogamie zusammenhängt, läßt sich noch nicht entscheiden". This supposition is now proved, as far as the Hieracia are concerned.

In my opinion, BATESON is therefore right in saying that no indisputable examples of non-segregating crosses have been found among plants, as the Hieracium hybrids, which apparently were a proof of non-segregation, have by my investigations been unravelled to be constant only on account of apogamy, and probably would segregate when crossed back with the parents. -

The results of our going through the literature do not seem to indicate that hybridization is of great importance for the origin of species. However, it would be too precipitate to deny its value absolutely. There are many facts to indicate that it is still of some consequence. Firstly, as already stated above, new constant forms can arise also in segregating hybrids through segregation during several generations. And secondly, we have our special case, Hieracium, where the artificially produced hybrids immediately act as new species which breed true from seed (on account of apogamy). In nature the same thing must happen; the hybrids act quite as normally sexual species and have consequently the same worth as these. However, this method of the origin of species has, as already pointed out by NAGELI and PETER, the restriction, that the hybridogenous new species do not bring new characters, but only new combinations of already existing 
characters, or as DE VRIES says (I903, p. 492): "Wenn auch durch Bastardierung keine neue Artmerkmale entstehen können, so können doch andererseits, zweifelsohne aus Bastarden neue Arten herrorgehen".

New species certainly arise through hybridization, but this method of the origin of species is limited to certain cases, e. g. Hieracium, and is checked in many ways.

\section{Literature.}

Bateson, W. (1909): Mendel's Principles of Heredity. Cambridge.

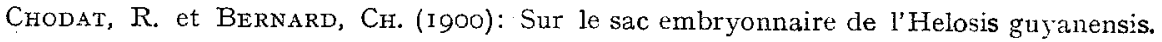
- Journ. de Botanique, vol. I4.

Correns, C. (1905): Gregor Mendels Briefe an Carl Nägeli I866-1873. Ein Nachtrag zu den veröffentlichten Bastardierungsversuchen Mendels. - Abh. d. math. phys. Kl. d. k. sächsischen Ges. d. Wiss., XXIX, Nr. 3, pp. 187-265.

DAY, D. F. (1896): Parthenogenesis in Thalictrum Fendleri. - Botan. Gazette, vol. 22, p. $24 \mathrm{I}$.

DingleR, H. (1907): Versuch einer Erklärung gewisser Erscheinungen in der Ausbildung und Verbreitung der wilden Rosen. - Mitt. naturhist. Ver. zu Aschaffenburg, Bd. 6 (quoted from H. Winkler 1908).

ERNST, A. (1866): A new case of parthenogenesis in the vegetable kingdom. - Nature, vol. 34, pp. 549-552.

- (rgog): Apogamie bei Burmannia coelestis Don. - Ber. d. Deutsch. Bot. Ges., XXVII, Heft 4.

- und Bernard, Ch. (Ig09): Bejträge zur Kenntnis der Saprophyten Javas. III. Ann. du Jardin botan. de Buitenzorg, 2. ser., vol. 8, I partie.

- und Schmid, ED. (1909): Embryosackentwicklung und Befruchtung bei Rafflesia Patma Bl. - Ber. d. Deutsch. Bot. Ges., XXVII, Heft 4.

Focke, W. O. (1881): Die Pflanzen-Mischlinge. Berlin.

Gates, R. R. (1907a): Pollen Development in Hybrids of Oenothera lata $\times$ O. Lamarckiana, and its Relation to Mutation. - Botan. Gazette, vol. 43, Februar.

- (1907b): Hybridization and Germ Cells of Oenothera Mutants, - Ibidem, vol. 44, July.

- (Igoga): The Behavior of Chromosomes in Oenothera lata $>0$ gigas. - Ibidem, vol. 48 , September.

- (rgogb): Apogany in Oenothera. - Science, N. S., vol. XXX, Nr. 776, November. Hedlund, T. (1907): Om artbildning ur bastarder. - Botan. Notiser, Lund, pp. 27-46, $49-6 \mathrm{r}$.

Johannsen, W. (1908): Uber Knospenmutation bei Phaseolus. - Zeitschr. f. indult. Abstamm. u. Vererbungslehre, Bd. I, Heft I.

- (1909): Elemente der exakten Erblichkeitslebre. Deutsche wesentl. erweiterte Ausgabe. Jena. 
Juel, H. O. (1898): Parthenogenesis bei Antemaria alpina (L.) R. Br. Vorläufige Mitteilung. - Botan. Centralbl., Bd. 74 .

- (1900): Vergleichende Untersuchungen über typische und parthenogenetische Fortpflanzung bei der Gattung Antennaria. - K. Svenska Vet. Akad. Haindl., Bd. 33, Nr. 5 .

- (1905): Die Tetradenteilungen bei Taraxacum und anderen Cichorieen. - K. Svenska Vet. Akad. Handl., 39, Nr. 4.

Kirchner, O. (1905): Parthenogensis bei Blütenpflanzen. - Ber. Deutsch. Bot. Ges., XXII, Generalversammlungsheft, pp. $\left(8_{3}\right)-(97)$.

Leavitr, R. G. and Spalding, L. J. (1905): Parthenogenesis in Antennaric. - Rhodora, vol. 7 , June.

LIDFORSS, B. (I905 \& I907): Studier öfver artbildningen inom släktet Rubus. Arkiv f. Botanik, Stockholm, Bd. 4 , Nr. 6 u. Bd. 6 , Nr. I6.

LindBeRG, H. (1909): Die nordischen Alchemilla vulgavis-Formen und ihre Verbreitung. - Acta Soc. Sc. Fennicae, tom. XXXVII, Nr. 10. Helsingfors.

Lock, R. H. (1909): A preliminary survey of Species Crosses in the Genus Nicotiana from the Mendelian Standpoint. - Ann. R. Bot. Gardens, Paradeniya, vol. IV, part V.

Lotsy, J. P. (I899): Balanophora globosa Jungh., eine wenigstens örtlich verwittwete Pflanze. - Ann. du Jardin botan. de Buitenzorg, vol. I6.

LundstRöm, E. (1909): Kastreringsförsök med Rosa-former. - Svensk Botan. Tidskr., Bd. 3 Heft I.

Mendel, G. (1870): Über einige aus künstlicher Befruchtung gewonnene HicraciumBastarde. - Verh. d. naturf. Ver. Brünn, VIII, Abhandl. pp. 26-3I. - Reprinted in Ostwalds Klassiker d. exakten Wiss., Nr. 121, pp. 47-53.

Meyer, K. (1909): Untersuchungen über Thismia clandestina. - Bull. des Natur. di Moscou, 18 pp., 2 Taf.

Modilewsky, J. (I908): Zur Samenbildung einiger Urticifloren. - Flora, vol. 98, igo8.

MURBECK, S. (1897): Om vegetativ embryobildning hos flertalet Alchemillor och den förklaring öfver formbeständigheten inom slältet, son densamma innebär. Botan. Notiser, Lund, December 1897 .

- (190I): Parthenogenetische Embryobildung in der Gattung Alchimilla. - Lunds Universitäts årsskrift, Bd. 36, Afd. 2, Nr. 7 .

- (1904): Parthenogenese bei den Gattungen Taraxacum und Hieracitm. - Botan. Notiser, Lund, December 1904.

Nägeli, C. von und Peter, A. (1885): Die Hieracien Mitteleuropas. I Piloselloiden. München.

Ostenfeld, C. H. (1904a): Zur Kenntnis der Apogamie in der Gattung Hicracium. - Ber. d. Deutsch. Bot. Ges., Bd. XXII, Heft 7 .

- (r904b): Weitere Beiträge zur Kenntnis der Fruchtentwicklung bei der Gattung Hieraciutm. - Ber. d. Deutsch. Bot. Ges., Bd. XXIII, Heft 9.

- (I906): Castration and Hybridisation Experiments with some Species of Hicracia. Botan. Tidsskr., Köbenhavn, Bd. 27, Heft 3 .

- (1907): Castration and Hybridisation in the Genus Hicracium. - Rep. 3 rd. internat. Conference 1906 on Genetics, London.

- og Raunkiaer, C. (1903): Kastrèringsforsög med Hicracium "g andre Cirhorieat. - Botan. Tidsskr., Köbenhavn, Bd. 25, Heft s. 
Overton, J. B. (1902): Parthenogenesis in Thalictrum purpurascens. - Botan. Gazette, vol. 33 .

Peter, A. (I884-85): Über spontane und künstliche Gartenbastarde der Gattung Hieracium, sect. Piloselloidea. - Englers Botan. Jahrb., vol. 5, pp. 203-286, 448-496, vol. 6, pp. III 136 .

- (1894): Hieracium, in Engler u. Prant1, Die Natürliche Pflanzenfam., IV. Teil, 5. Abt., pp. $375-387$.

Poulsen, V. A. (1905): Sciaphila nana Bl. Et Bidrag til Stövvejens Udvikling hos Triuridaceerne. - Vidensk. Medd. Naturhist. Forening, Köbenhavn, f. Igo6.

Raunktaer, C. (1903): Kimdannelse uden Befrugtning hos Mälkebötte (Taraxacum). Botan. Tidsskr., Köbenhavn, Bd. 25, Heft 2.

Rosenberg, O. (Igo6): Uber die Embryobildung in der Gattung Hieracium. - Ber. Deutsch. Bot. Ges., XXIV, Nr. 3.

- (I907): Cytological Studies on the Apogamy in Hieracium. - Botan. Tidsskr., Köbenhavn, Bd. 28, Heft $\mathrm{I}-2$.

- (1909): Uber die Chromosomenzahlen bei Taraxacum und Rosa. - Svensk Botan. Tidskr., Bd. 3, Heft 2.

Schultz, F. (1856): Plantes hybrides. - Archives de Flore, Journal botanique, II, p. 254-255. Wissembourg.

Shibata, K. u. Miyake, K. (1908): Uber Parthenogenesis bei Houttuynia cordata. Botan. Magazine, Tokyo, XXII, Nr. 26r.

Strasburger, E. (1904): Die Apogamie der Eualchimillen und allgemeine Gesichtspunkte, die sich aus ihr ergeben. - Jahrb. f. wissensch. Botanik, Bd. 4I, Heft I.

- (I909a): Zeitpunkt der Bestimmung des Geschlechts, Apogamie, Parthenogenesis und Reduktionsteilung. - Histologische Beitr., VII. Jena.

- (1909b): Meine Stellungnahme zur Frage der Pfropfbastarde. - Ber. d. Deutsch. Botan. Ges., vol. 29, Heft 8.

Thomas, Mrs. Rose Haig (1909): Parthenogenesis in Nicotiana. - The Mendel Journal, No. I.

Tischler, G. (1908): Zellstudien an sterilen Bastardpflanzen. - Archiv f. Zellforschung, Bd. I, Heft I.

Trevi, M. (I898): L'organe femelle et l'apogamie du Balanophova elongata. - Ann. du Jardin botan. de Buitenzorg, vol. I 5 .

- (1902): L'organe femelle et l'embryogénèse dans le Ficus hivta Vahl. - Ibidem, 2. sér., vol. 3 .

- (1905): L'apogamie de l'Elatostemma acuminatum Brongn. - Ibidem, 2. sér., vol. 5.

Vollmann, F. (1909): Die Bedeutung der Bastardierung für die Entstehung von Arten und Formen in der Gattung Hieracium. - Ber. XII der Bayer. Botan. Ges., München.

De Vries, H. (1902-03): Die Mutationstheorie, Bd. II. Leipzig.

- (1906): Species and Varieties. Their Origin by Mutation. 2 ed. Chicago \& London.

- (1907): On Twin Hybrids. - Botan. Gazette, vol. 44, December.

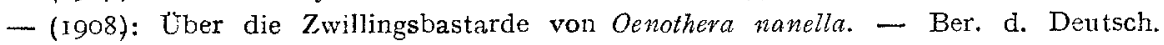
Botan. Ges., Bd. XXVIa, Heft 9.

Wettstein, R. v. (I904): Die Erblichkeit der Merkmale von Knospenmutationen. Festschrift für Ascherson, Berlin.

- (1908): Uber sprungweise Zunalime der Fertilität bei Bastarden. - WiesnerFestschrift, Wien. 
:
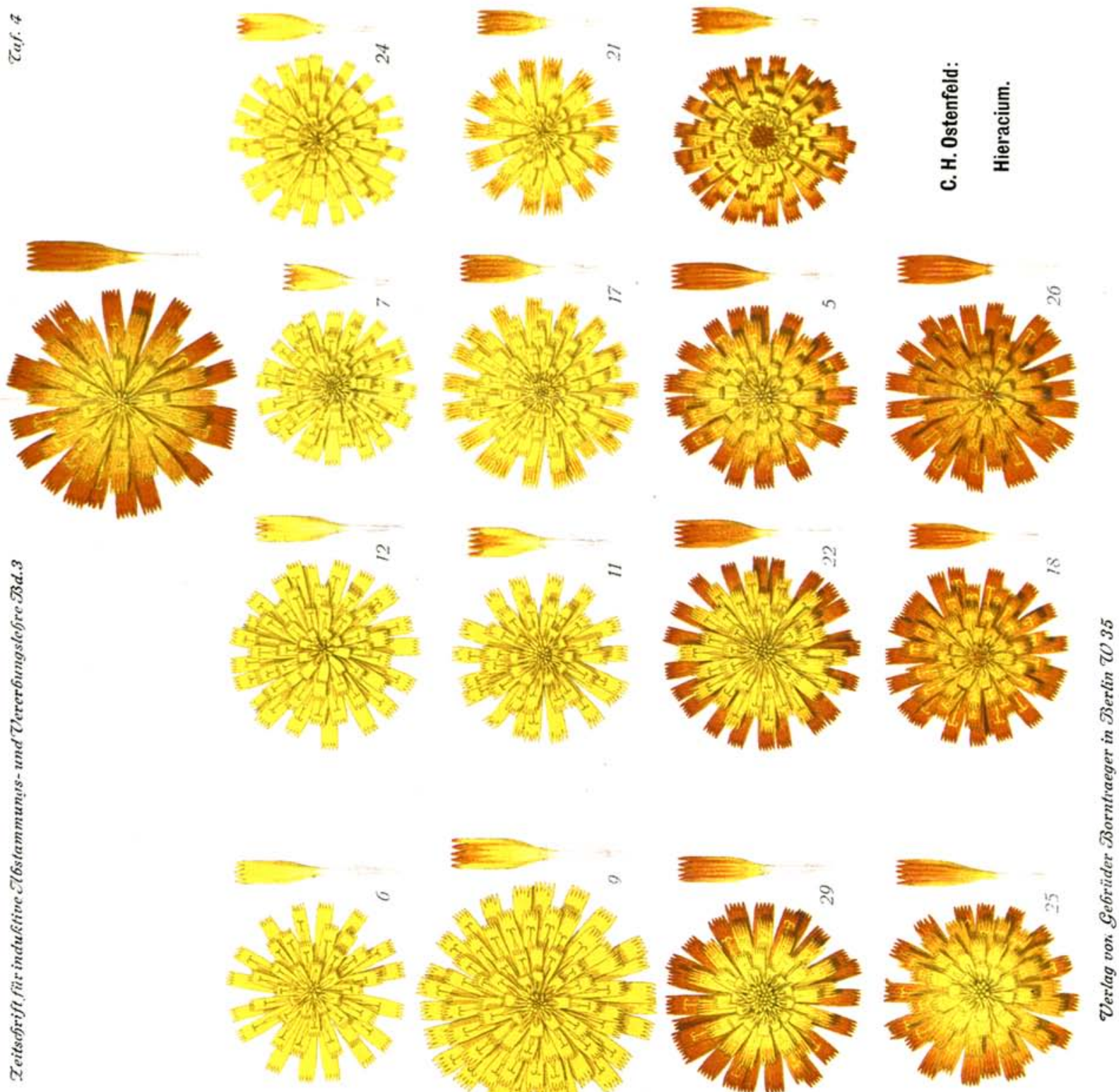

a ling o
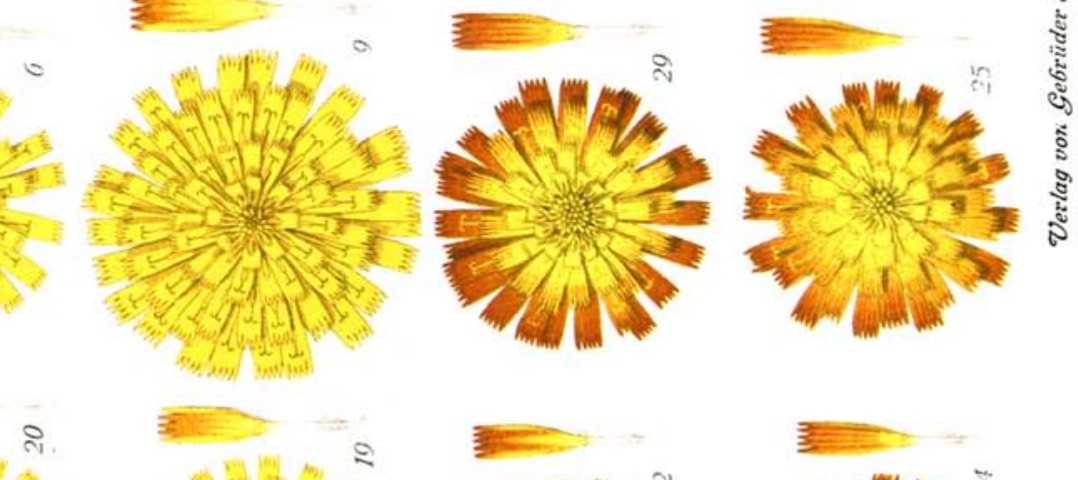

柆
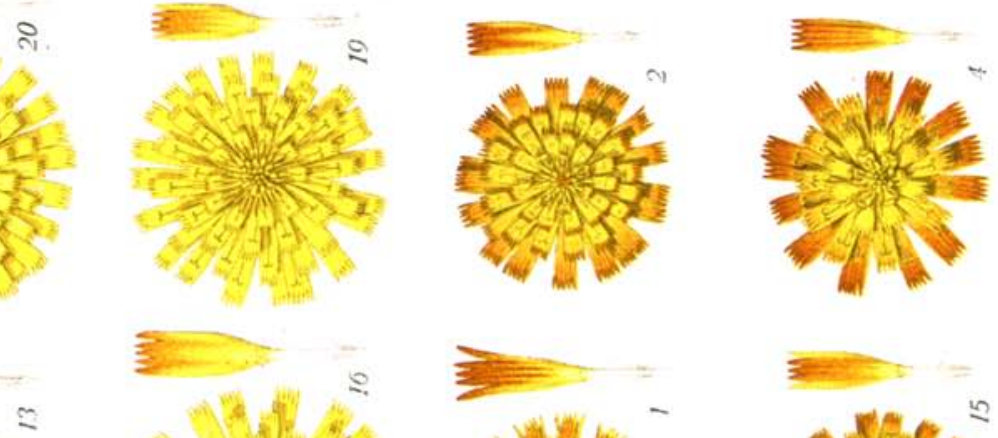

$\frac{\int^{2}=}{2 x^{2}}$
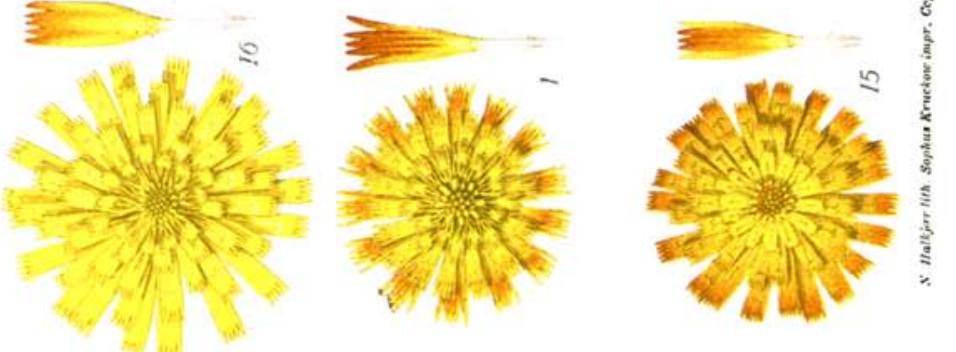
Winkler, Hans (I904): Uber Parthenogenesis bei Wikströmia indica (L.) C. A. Męy. - Ber. d. Deutsch. Bot. Ges., XII, Heft to.

- (1906): Botanische Untersuchungen aus Buitenzorg II. 7. Cber Parthenogenesis bei Wikströmıa indica (L.) C. A. Mey. - Ann. Jard. Bot. Buitenzorg, 2. sér., vol. V. - (I908): Parthenogenesis und Apogamie im Pflanzenreiche. - Progressus Rei Botan., Bd. 2, Heft 3.

- (1909): Weitere Mitteilungen über Pfropfbastarde. - Zeitschr. f. Botanik, I, Heft 5.

$$
\text { Explanation of Plate } 4 .
$$

Reproduction of coloured drawings of flowering heads, seen from above and of the outer flowers, seen from below $(3 / 2$ and $3 / 1$ nat. size). Uppermost: Hieracium auricula and $H$. aurantiacum. Beneath: 23 specimens of one and the same family of hybrids between these two species. The figures have protocol numbers; but the arrangement here used should show the gradation in flower colour, reaching from the yellow mother to the orange-red father. This gradation is not correlated to the vegetative characters.

The drawings have been made by Mr. N. HALKJAER.

\section{Referate.}

Lang, A. Über Vererbungsversuche. 3. Fig. i. T. und 2 Taf. Verhandl. Deutsch. Zoologischen Gesellschaft Igog. S. I7-84.

In experimentellen Untersuchungen über Vererbung, Bastardierung und Artbildung haben während der letzten Jahre unstreitig die Botaniker die Führung gehabt. Die Zoologen haben sich sehr zurückgehalten und ganz besonders gilt dies für die deutschen Zoologen. Das scheint jetzt anders zu werden. Auf der letzten Tagung der Deutschen Zoologischen Gesellschaft haben gerade Vererbungsfragen die wichtigste Rolle gespielt. Ref. erinnert hier nur an die ausgezeichneten Untersuchungen an Daphniden, über die Woltereck berichtet hat. Die erweiterte Wiedergabe eines andern, auf der gleichen Tagung gehaltenen Vortrages von A. Lang liegt in der hier zu referierenden Abhandlung vor. Die Arbeit gibt in klarer, gedrängter Form eine speziell für Zoologen bestimmte erste Einführung in die wichtigsten Ergebnisse und die neuen Fragestellungen der ,,exakten Erblichkeitslehre", um mit Johannsen zu reden. Daß diese Einführung inhaltlich vollkommen auf der Höhe ist, braucht wohl nicht erst hervorgehoben zu werden, und es ist auch wohl nicht nötig, auf Einzelheiten hier einzugehen. In allen prinzipiellen Fragen vertritt Lang Anschauungen, die denjenigen Johannsens und wohl der Mehrzahl der ibrigen experimentell arbeiten. den Botaniker ungefähr entsprechen.

Möge die anregend geschriebene Abhandlung Propaganda machen! Es gibt doch sehr zahlreiche Tiere, deren Kultur, auch bei sehr großen Individuenzahlen nicht mehr Mühe macht als die Kultur der Pflanzen. Besonders für die Frage der experimentellen Auslösung von Mutationen nach dem Beispiel der wichtigen Untersuchungen Towers dürften sicher auch viele andere Tiere gute Versuchsobjekte abgeben, bessere als im allgemeinen die 